\title{
Yahya Kemal'in Kitaplarında Yer Almayan Bazı Yazıları
}

\section{Some of Yahya Kemal's Articles that are not Published in His Book}

\author{
Ali Şükrü Çoruk ${ }^{1 \oplus}$
}

'Prof. Dr., İstanbul Üniversitesi, Edebiyat Fakültesi, Türk Dili ve Edebiyatı Bölümü, İstanbul, Türkiye

\author{
Sorumlu yazar/Corresponding author: \\ Ali Şükrü Çoruk, \\ İstanbul Üniversitesi, Edebiyat Fakültesi, Türk Dili \\ ve Edebiyatı Bölümü, İstanbul, Türkiye \\ E-mail: alisukrucoruk@gmail.com
}

Geliş tarihi/Date of receipt: 19.11.2018

Kabul tarihi/Date of acceptance: 05.12.2018

\section{Atıf/Citation:}

Çoruk, A. Ş. (2018). Yahya Kemal'in kitaplarında yer almayan bazı yazıları. TUDED 58(2), 345-373. https://doi.org/10.26650/TUDED496219

\section{ÖZET}

Şairlerin ve yazarların ortaya koyduğu edebî metinlerin tam bir külliyat hâlinde okuyucu ve araştırmacının istifadesine sunulamaması dün olduğu gibi bugün de edebiyat araştırmalarının temel problemi olmaya devam etmektedir. Çünkü çeşitli yollarla, zaman içinde şairlere ve yazarlara ait yeni bilgiler, belgeler ve metinler ortaya çıkmaktadır. Türk şiirinin önemli isimlerinden Yahya Kemal de bu şair ve yazarlardan birisidir. Yaşarken eserlerini kitap hâlinde bastırmamış olan Yahya Kemal'in yazı ve şiirleri vefatından sonra Nihad Sami Banarlı tarafından bir külliyat şeklinde neşredilmiştir. Yahya Kemal'in yakın çevresinden Nihad Sami Banarlı́nın gerçekleştirdiği bu neşriyat, gazete ve dergilerde yayınlananların dışında özellikle daha önce hiçbir yerde yayınlanmamış el yazısı makale, yazı, şiir ve notları da içermesi bakımından oldukça önemlidir. Bununla beraber şairin bu külliyatta yer almayan bazı eserleri daha sonra ortaya çıkmış ve araştırmacılar tarafından yayınlanmıştır. Bu makalede Yahya Kemal'in 1920 yılında Akşam gazetesinde neşredilen, ancak sonradan oluşturulan külliyatında yer almayan "***iki yıldız)" imzalı 7 yazısı konu edilmektedir. Makalenin birinci ve ikinci bölümlerinde, elde edilen ipuçlarından hareketle bu yazıların Yahya Kemal'e ait olduğu bilgisine nasıl ulaşıldığı tartışıımıştır. Üçüncü bölümde yazılar hakkında kısa notlar hâlinde bilgi verilip, bu yazılarla Yahya Kemal'in diğer yazıları arasındaki ortak noktalar tespit edilmeye çalışıımıştır. "Metinler" bölümünde ise yazılar Latin harflerine aktarılarak verilmiştir.

Anahtar Kelimeler: Yahya Kemal, tartışma, Yusuf Ziya, Millî Mücadele, gazete

\section{ABSTRACT}

Failing to provide literary texts that are written by poets and authors themselves, as an oeuvre, for the benefit of its readers and researchers, still remains a fundamental problem of literary research. One of the continuing problems is that new information, documents, and texts by poets and authors arise over time through different means. Yahya Kemal, the prominent Turkish poet, is one such poet and author. His poems and letters, which were unpublished into book form while he was alive, have been posthumously published as a collection by Nihad Sami Banarlı. Such a publication from a person within Yahya Kemal's inner circle is of high importance, as it contains his hand-written articles, letters, poems, and notes that have not been published before, except the ones published in newspapers and journals. However, some of his work, which has been omitted from the said collection, has come to light and has been subsequently published by researchers. This article seeks to address the seven letters signed by **, which have not been included in the collection published by Banarlı but were published in the newspaper Akşam in 1920.

Keywords: Yahya Kemal, discussion, Yusuf Ziya, War of Independence, newspaper 


\section{EXTENDED ABSTRACT}

Failing to provide literary texts that were written by poets and authors themselves, as an oeuvre, for the benefit of its readers and researchers, still remains a fundamental problem of literary research. One of the continuing problems is that new information, documents, and texts by poetsand authors arise over time through different means. The prominent Turkish poet, Yahya Kemal, is one such poet and author. His poems and letters,which were unpublished into book form while he was alive, have been posthumously published as a collection by Nihad Sami Banarlı. Such a publication from a person within Yahya Kemal's inner circle, is of high importance, as it contains his hand-written articles, letters, poems, and notes that have not been published before, except the ones published in newspapers and journals. However, some of his work, which has been omitted from the said collection, has come to light and has been subsequently published by researchers. This article seeks to address the seven letters signed by ${ }^{* *}$, which have not been included in the collection published by Banarlı but were published in the newspaper Akşam in 1920. In the first and second sections, we discuss how it was determined that the letters were written by Yahya Kemal, in line with the collated evidence. In the third section, we provide short notes about the letters and seek to identify the commonalities between the letters being examined and other letters written by Yahya Kemal. In the "Texts" chapter, we provide Latin transcriptions of the letters.

Several letters that we have analyzed in this article are important for the history of literature. Certain letters contain Kemal's responseson the debate Dünküler-Bugünküler (Of Yesterdays-Of Todays), which was initiated by young poets, Yusuf Ziya (Ortaç) in particular, against poets such as Yahya Kemal and Cenap Şahabettin. His letters, such as Genç ve Yeni (Young and New), Güzel Yazılar (Fine Letters), Edebiyatta Münakaşa (Debate in Literature), and Edebiyatta Cehalet (Ignorance in Literature) are crucial, as they shed light on a debate that has not been discussed much, revealing Kemal's critical side. The letters Vatan ve Muallim Naci (Homeland and Naci the Teacher) and Vatan ve Abdülhak Hamid (Homeland and Abdülhak Hamid) address the opinions of such poets regarding homeland. His letter Iki Mübariz Ruh (Two Warrior Souls) is significant, as it indicates how his pro-National Struggle opinions were reshaped over time. As it is known, Kemal did not publish his work in book form during his lifetime, with his writings and poems posthumously published as a corpus by Nihad Sami Banarlı. This publication, produced by Nihad Sami Banarlı within the İstanbul Fetih Cemiyeti, is of great importance because it contains unpublished hand-written articles, writings, poems, and notes,except for some work that was published in newspapers and magazines. However, some of Yahya Kemal's work, which is not included in this corpus, has surfaced in the last few years and has been published by researchers. It appears that such publications will continue, especially as new findings are discovered, for Yahya Kemal in particular and for other writers and poets in general. These writings, which can be divided into two categories political and literary contain important information with regard to understanding the history of literature, as 
well as understanding Yahya Kemal's world of thought. As discussed below, these writings, which we consider as a contribution to the corpus of Yahya Kemal, were written during the time of a debate that took place in the Armistice period of our literary history, which we call Dünküler-Bugünküler (Of Yesterdays-Of Todays).These findings are noteworthy, as they contain the opinions of Yahya Kemal, who was accused of being one of the Dünküler (Of Yesterdays) in literature by young poets led by Yusuf Ziya (Ortaç). His political writings are also of great importance in terms of showing how the poet's opinions, in favor of the war of independence, took shape over time. 


\section{Gíriş}

Aralarında tanınmış şahsiyetlerin de yer aldığı pek çok şairin ve yazarın kaleme aldığı eserlerin tam bir külliyat hâlinde okuyucu ve araştırmacının istifadesine sunulamaması dün olduğu gibi bugün de edebiyat araştırmalarının temel problemi olmaya devam etmektedir. Öncelikle bu konuda yapılan çalışmaların ve ortaya konulan çabaların şimdiki hâlde önemli bir boşluğu doldurduğunu belirtelim. İşin tabiatı gereği böyle bir çalışmanın kendisine has birtakım zorlukları barındırdığı ortadadır. Yazarların ve şairlerin vefat ettikten sonra geriye kalan evraklarının tek elde muhafaza edilememesi, farklı kişilere ve kurumlara dağılan bu evraklardan bazılarının şans eseri gün ışığına çıkması, kişisel ve kurumsal arşivlerin henüz bütünüyle tasnif edilmemesi, kütüphanelerimizde mevcut bulunan özellikle eski yazı gazete ve dergi koleksiyonlarının tam olmaması, müstear isimler ve rumuzlar meselesi, bu konuda akla ilk gelen zorluklardan bazılarıdır.

Bilindiği üzere sağlığında eserlerini kitap hâlinde bastırmamış olan Yahya Kemal'in yazıları ve şiirleri vefatından sonra Nihad Sami Banarlı tarafından bir külliyat şeklinde neşredilmiştir. Yahya Kemal'in yakın çevresinden Nihad Sami Banarlı'nın İstanbul Fetih Cemiyeti bünyesinde gerçekleştirdiği bu neşriyat, gazete ve dergilerde yayınlananların dışında özellikle daha önce hiçbir yerde yayınlanmamış el yazısı makale, yazı, şiir ve notları da içermesi bakımından oldukça önemlidir. Bununla beraber şairin bu külliyatta yer almayan bazı eserleri daha sonra ortaya çıkmış ve araştırmacılar tarafından yayınlanmıştır. Öyle görülüyor ki özelde Yahya Kemal, genelde ise diğer yazar ve şairlerimiz hakkında, yeni bulgular ışığında bu tarzda yayınlar yapılmaya devam edilecektir. Nitekim yaptığımız araştırmalar sonucunda kaleme aldığımız bu yazının konusunu da 1920 yılında Akşam gazetesinde yayınlanan ve Yahya Kemal'e ait olduğuna inandığımız, şairin külliyatında yer almayan 7 yazı teşkil etmektedir. Siyasî ve edebî olarak ikiye ayırabileceğimiz bu yazılar gerek edebiyat tarihi açısından gerekse Yahya Kemal'in düşünce dünyasını daha iyi anlamak adına önemli bilgiler içermektedir. Aşağıda tartışılacağı üzere, Yahya Kemal külliyatına katkı olarak gördüğümüz bu yazılardan bazıları edebiyat tarihimizde Mütareke döneminde yaşanan ve adına "Dünküler-Bugünküler" diyebileceğimiz bir tartışma sırasında yazıımıştır. Dolayısıyla bunlar, başını Yusuf Ziya (Ortaç)'ın çektiği gençler tarafından “Dünküler"den biri olarak suçlanan Yahya Kemal'in edebiyat hakkındaki düşüncelerini içermesi bakımından dikkate değer niteliktedir. Siyasî içerikli yazılar ise şairin Millî Mücadele lehindeki fikirlerinin zaman içinde nasıl şekillendiğini göstermesi açısından mühimdir. ${ }^{1}$

Hemen söyleyelim ki sözünü ettiğimiz yazılarda imza yoktur ve imza yerine ** işareti konulmuştur. Mütareke ve işgal İstanbul'unun zor şartları altında, gazetelerde imza yerine sıklıkla rumuz ve işaret kullanıldığı bir dönemde neşredilen bu yazıların Yahya Kemal tarafından yazıldığına dair kanaate ise aşağıda görüleceği üzere gazete taramalarından elde ettiğimiz bilgi kırıntılarını bir araya getirerek ulaştık. Elbette hükme varırken bu

1 Bu çalışma sırasında yardımlarını gördüğüm meslektaşım Arş. Gör. Sevim Güldürmez'e teşekkür ederim. 
yazılarla şairin diğer yazılarını gerek konu gerekse üslup yönüyle mukayese edip sonuca gitmeyi ihmal etmedik. Makalenin ekinde ise Yahya Kemal'e ait olduğunu düşündüğümüz yazıları Latin alfabesine aktardık.

\section{Mütareke Döneminde Garip Bir Edebiyat Tartışması: Dünküler-Bugünküler}

Yahya Kemal'in bu makaleye zemin teşkil eden Akşam'daki yazılarından haberdar olmamız Mütareke döneminde yaşanan bir edebî münakaşa vesilesiyledir. Başlı başına bir makale konusu olan ve 1929 yılında yaşanan "Putları Yıkıyoruz" hareketinin bir benzeri niteliğindeki bu münakaşanın ana hatları şöyledir: Mütareke döneminde, aralarında Yusuf Ziya (Ortaç), Halit Fahri (Ozansoy) ve Orhan Seyfi (Orhon)'un bulunduğu bir grup genç şair bir araya gelerek eserlerini Birinci Kitap, İkinci Kitap şeklinde neşretmeye başlarlar. Genç şairlerin bu teşebbüsü olumlu karşılandığı gibi birtakım tenkitlere de maruz kalır. Genç şairlere yöneltilen eleştirilerin ortak noktası ülkenin yaşadığı meselelere duyarsız kalarak çok ferdî konular etrafında şiirler yazmaları, dil konusunda yaptıkları hatalardır. Özellikle kendilerinden önceki nesil tarafından dile getirilen bu tenkitler başta Yusuf Ziya olmak üzere genç şairler tarafından tepkiyle karşılanır. Arkadaşlarının bir anlamda sözcülüğünü yapan Yusuf Ziya modernlik içinde bir Dünküler-Bugünküler yani eskilik-yenilik tartışması başlatır. Yusuf Ziya'nın önce ima yoluyla daha sonra da açıkça isim vererek hedefine aldığı ve "Dünküler" olarak nitelediği isimler Cenap Şahabettin, Ahmet Haşim ve Yahya Kemal'dir. Ona göre miadlarını dolduran bu isimlerin yerlerini yenilere yani “Bugünküler"e bırakmaları gerekir. $^{3} 1920$ yılının ikinci yarısında alevlenen tartışma sırasında bizim konumuzla alakalı olarak Akşam gazetesinde isim belirtilmeden yenileri eleştiren yazılar çıkmaya başlar. 0 dönemde Alemdar gazetesinin "edebî nüsha"sını hazırlayan Yusuf Ziya bu yazıların Yahya Kemal tarafından yazıldığını öğrenir ve tartışmada önemli bir mevzi kazanmak adına Yahya Kemal'i zor duruma düşürmek için harekete geçer. Aşağıda temas edeceğimiz bir tertip doğrultusunda Yahya Kemal'in yazdığı ve söylediği şiirlerin Fransız şairlerden çalıntı olduğuna inanan Yusuf Ziya, "Akşam gazetesi muharrir-i edebîsi Yahya Kemal Bey'in bütün edebî kıymetini tahlil ve Fransız edebiyatından aynen tercüme ederek şiir namı altında ortaya attığı mısraların asıllarını ihtiva eden" bir yazı ile Yahya Kemal'e karşııı vermeyi düşünür.

2 Şairler, Birinci Kitap, Ikinci Kitap başlıklarıyla her ay bir kitap neşretmeyi hedeflemişlerdir. Birinci Kitap Ocak 1920'de çıkmıştır. Bununla beraber Beşinci Kitap'tan sonra yayın periyodunda aksamalar olmuş, Altıncı Kitap Temmuz 1920'de, Yedinci Kitap Aralık 1920'de, son kitap olan Sekizinci Kitap ise Şubat 1921'de neşredilmiştir. Orhan Seyfi, Halit Fahri, Yusuf Ziya, Faruk Nafiz, Halide Nusret ve Nazım Hikmet, az da olsa hikâye ve tiyatro metinlerinin de yer aldığı bu kitaplarda şiirleri yayınlanan başlıca şairlerdir.

3 Bu edebiyat tartışmasında "Yeniler"in yanında yer aldığı anlaşılan Alemdar gazetesi haftada bir kez neşrettiği "Edebî Nüsha"sıyla sayfalarını genç şairlerin ürünlerine ve değerlendirme yazılarına açar. "Edebî Nüsha"yı yöneten muharrir ise gençlerin sözcüsü durumundaki Yusuf Ziya'dır. Yusuf Ziya "Dünküler" olarak nitelendirdiği şairleri gerek yazılarında gerekse yaptığı röportajlarda eleştirir. Bu yazıların ilkinde yer alan "Bilhassa bizim gibi gıdası az çok hayal olan bir millete Yahya Kemal'in yeni bir mısraı Varşova'nın sukutundan ziyade mühim bir dedikodu mevzuudur... Maksadım ne otuz sene evvel köhne hücumların kademelerine basarak yükselen dünkü nesle ta'rizdir, ne de onlardan gelecek hücumlara karşı susmaktır... Şüphesiz fikrimiz ve hissimiz ilk gıdayı onlardan aldı. Fakat unutmamalıdır ki bir de bugün var, bugünküler var." cümleleri "Dünküler" karşısında nasıl bir tutum sergileyeceklerini önceden haber vermektedir. (Bkz. "Başlarken", Alemdar, nr. 2899-599, 14 Ağustos 1920, s. 3. ) 
Alemdar gazetesi Yusuf Ziya'nın bu konuda kaleme aldığı makalenin 16 Teşrinievvel (Ekim) 1920 tarihli nüshasında yayınlanacağını bir gün önceden ve birinci sayfadan okuyucularına duyurur. ${ }^{4}$ Yusuf Ziya'nın yazısı ertesi günkü Alemdar'da çıkar. Ancak yazıda, ilânda sözü edilen husus yani Yahya Kemal'in Fransız şairlerden "aynen tercüme ederek" aldığı mısralarla ilgili bir bahis yer almaz. Bununla beraber bizim açımızdan çok önemli bir noktaya işaret eder: Yusuf Ziya yazısında edebî ağırlıklı olmak üzere Akşam gazetesinde neşredilen ve imza yerinde "**, mim, elif **" işaretleri bulunan yazıların çoğunluğunun Yahya Kemal'e ait olduğunu iddia eder. ${ }^{5}$ Nitekim bu iddia aşağıdaki açıklamasında da göreceğimiz üzere Yahya Kemal tarafından yalanlanmayacaktır. ${ }^{6}$

Alemdar gazetesinde kendisi hakkında çıkan ilân ve Yusuf Ziya'nın ertesi gün neşredilen yazısı hakkında Akşam gazetesine bir mektup gönderen Yahya Kemal oldukça mizahî bir dille olanlardan haberli olduğunu kuvvetle bize hissettirir. Akşam gazetesinde 17 Teşrinievvel (Ekim) 1920'de neşredilen mektubunda, yaptığı intihaller dolayısıyla edebiyat dünyasında olumlu bir şöhrete sahip olmamakla suçladığı Yusuf Ziya'yı dolandırıcı roman kahramanı "Arsen Lüpen"e benzeten Yahya Kemal, kendinden emin bir şekilde, yazdığı şiirlerin “Fransızcada veya diğer bir lisandaki asıllarını Alemdar gazetesi ne gelecek hafta, ne öbür hafta, hiçbir hafta neşredemeyecektir" diyerek böyle bir edebiyat oyununda düştüğü durumdan dolayı Yusuf Ziya ve Alemdar gazetesiyle alay eder. ${ }^{7}$ Kuşkusuz bu kendinden emin meydan okuma karşısında Yusuf Ziya'nın yapacak fazla şeyi yoktur.

4 Alemdar gazetesinde konuyla ilgili olarak yayınlanan ilânın tam metni şöyledir: "Aynı zamanda bu nüshamızda [16 Teşrinievvel] genç nesle "cahil" diyen Akşam gazetesi muharrir-i edebîsi Yahya Kemal Bey'in bütün edebî kıymetini tahlil ve Fransız edebiyatından aynen tercüme ederek şiir namı altında ortaya attığı mısraların asıllarını ihtiva eden Yusuf Ziya Bey'in çok meraklı ve şayan-ı dikkat bir makalesi bulunacaktır." (Alemdar, nr. 2957-657, 15 Teşrinievvel (Ekim) 1920, s. 1).

5 Yusuf Ziya bu yazıında Yahya Kemal'in kiş̧iliğini ve sohbet ortamında söylediği bazı sözleri tariz maksadıyla vermekle yetinir. Yazının bizim açımızdan önemli tarafı Akşam'da yayınlanan ve bu yazının konusu olan yazılarla ilgili yaptığı açıklamadır: "Birkaç zamandan beri Akşam gazetesinde güya edebî bir kanaatin muhtelif mevzular üzerindeki hareketi gibi gözükmek isteyen makaleler bunlardan başlıcasıdır (....) Biz cevabımızı istediğimiz gibi verebilmek için söyleyelim ki ${ }^{* *}, \mathrm{mim}$, bir elif iki yıldız imzalarını taşıyan bu şifreli makalelerin ekserisi Yahya Kemal Bey tarafından yazılmaktadır." (Yazı için bkz. "Hücum Karşısında-1", Alemdar, nr. 2958-658, 16 Teşrinievvel (Ekim) 1920, s. 3.)

6 Yusuf Ziya'nın bu iddiasının Yahya Kemal tarafından yalanlanmaması dikkat çekicidir. Bununla beraber Akşam gazetesinde bizim tarama yaptığımız dönemde imza yerinde "mim" işareti olan bir yazıya rastlamadığımızı ifade edelim. Ayrıca 6 Teşrinievvel (Ekim) 1920 tarihli ve "elif **" işaretli tek yazının ise Ahmet Haşim tarafından yazıldığını belirtelim. (Bkz. "Paris Görmüş Bir Zat", Ahmet Haşim-Bütün Eserleri III, Haz. İnci Enginün-Zeynep Kerman, TDK Yayınları, İstanbul 1991, s. 117-119)

7 Daha önce Adnan Akgün tarafından yeni harflerle neşredilen (bkz. Agm, s. 95) mektubun konumuzla ilgili kısımlarını aşağıya alıyoruz.

“Cuma günü [15 Teşrinievvel] çıkan Alemdar gazetesinin baş sahifesinde şöyle bir ilân gördüm 'Yarın çıkacak olan edebî nüshamızda ... Yahya Kemal Bey'in bütün edebî kıymetini tahlil ve Fransız edebiyatından aynen tercüme ederek şiir namı altında ortaya attığı mısraların asıllarını ihtiva eden Yusuf Ziya Bey'in çok meraklı ve şayan-ı dikkat bir makalesi bulunacaktır'.

Ferdası gün Alemdar'a baktım, 'aynen tercüme ederek ortaya attığım mısraların asılları' yok, bir yaygara sütunu vardı. Bu işâayı vaat eden Yusuf Ziya Bey'e birçok muharrirlerden ve bendenizden el çabukluğuyla piyes mevzuu ve şiir mazmunu aşırmaktaki maharetine nisbetle 'hece vezninin Arsen Lüpen'i diyorlar (...) Alemdar gazetesinin karilerini gelecek haftaya intizardan kurtarmak için arz ederim ki imzamla neşrettiğim 
Yusuf Ziya'nın Alemdar'da ilân edilen konuya girememesine gelince, genç şair bu konuda Dârülfünûn Edebiyat Fakültesi talebelerinin tabiri caizse bir oyununa gelmiştir. Şöyle ki, matbuatta "Dünküler-Bugünküler" tartışması başlatan ve "Dünküler"e yüklenen Yusuf Ziya'ya, hocaları Yahya Kemal ve Cenap Şahabettin'i eleştirdiği için Dârülfünûn Edebiyat Fakültesi öğrencileri bir oyun tertip ederler. Maksatları hocaları hakkında dönemlerini tamamladıkları yönünde eleştirel yazılar yazan Yusuf Ziya'nın Batı edebiyatına olan nüfuzunu ölçmek, dolayısıyla bu konudaki "cehaletini" ortaya koymaktır. Buna göre içlerinden bazıları Yahya Kemal'in tanınmış birkaç mısraını ve beytini Fransızcaya çevirirler ve bunların karşısına şairin çok önemsediği José Maria de Heredia, Henri de Régnier, Maurice Maeterlinck gibi Fransız ve Batılı şairlerin isimlerini koyarak Yahya Kemal'in yazdığı ve söylediği şiirlerin çoğunun Batılı şairlerden tercüme olduğu şeklindeki bir notu bir şekilde Yusuf Ziya'ya ulaştııılar. Yusuf Ziya'nın daha sonra neşredeceği bu nottan anladığımıza göre Batılı şairlerin isimleri ile şiirler birbirine karıştırılarak iş daha da içinden çıkılmaz bir hâle getirilmiştir. ${ }^{8}$ Bu notu eline geçiren ve "Dünküler"i eleştirmek konusunda eline çok önemli bir fırsat geçtiğini düşünen Yusuf Ziya vakit geçirmeden Alemdar gazetesinde yukarıda sözünü ettiğimiz ilânın çıkmasını sağlar. Ancak kısa süre sonra bunun tipik bir "asparagas" haber olduğunu öğrenir, fakat iş işten geçmiştir. Dolayısıyla Yahya Kemal hakkındaki yazıyı gazetede ilân ettiği şekilde yazamaz. Kısa sürede gazetelere yansıyan konu edebiyat tarihimiz açısından ilginç, bir o kadar da gülünç bir hâl alır. Şunu da söylemek gerekir ki olayların gidişatından ve yazılanlardan bu tertibin içinde Yahya Kemal'in de olduğu anlaşılmaktadır. ${ }^{9}$

beş on ufak tefek manzumenin Fransızcada veya diğer bir lisandaki asıllarını Alemdar gazetesi ne gelecek hafta, ne öbür hafta, hiçbir hafta neşredemeyecektir." ("Yahya Kemal Bey'in Mektubu”, Akşam, nr. 742, 17 Teşrinievvel (Ekim) 1920, s. 3).

8 Yusuf Ziya'nın Batı şiiri karşısındaki dikkatini ölçmek için hazırlanan ve yazar tarafından 23 Teşrinievvel (Ekim) 1920 tarihinde Alemdar gazetesinde (nr. 2958-658, "Hücum Karşısında-2", nr. 2958-658, s. 3) yayınlanan notta yer alan şu ibare bunlardan birisidir: "Henri de Régnier'in Les Syrtes'inin 132. sayfasındaki 'Angelos' manzumesinden... Hâlbuki Les Syrtes Henri De Régnier'in değil Jose Moreas'ın eseridir ve 98 sayfadır. Ayrıca kitapta böyle bir şiir yoktur. Bundan başka Yahya Kemal'in Heredia'dan tercüme ettiği ve öğrencisi Mustafa Nihad Özön'ün bu tartışma sırasında belirttiği üzere (Bkz. "Edebi Bir Mudhike", Dersaadet, nr. 100, 23 Teşrinievvel (Ekim) 1920, s. 3) Dârülfünûn'daki derslerinde işlediği, ancak muarızları tarafından daha sonraki dönemde intihalle suçlanmasına sebep olan meşhur mısra da (Les déesses de marbre et les héros d'airain/Ve kahramanları tunç alihâtı mermerden) bu notun hemen başında yer almıştır. Muhtemelen Yahya Kemal'in öğrencileri (Acaba aralarında Ahmet Hamdi Tanpınar da var mıydı?) Yusuf Ziya işin başında şüphelenmesin diye böyle bir yola gitmiş olabilirler. Notta yer alan diğer örnekler ise Yahya Kemal'in kendi mısraları ile bunların Fransızca tercümeleridir. Başka bir deyişle bu mısraların notta adı verilen Fransız şairleriyle ilgisi yoktur. Bununla beraber böyle bir tertibin Yusuf Ziya kadar olmasa bile Yahya Kemal'e de zarar verdiği, Heredia'dan tercüme ettiği ancak telif gibi gösterilen yukarıdaki mısraın kendi mısraıymış gibi algılanmasına yol açtığı açıktır. Kısaca temas ettiğimiz bu konuyu ilerde müstakil bir yazı hâlinde ele almayı düşündüğümüzü burada belirtelim.

9 Tartışma sırasında Yahya Kemal'in tarafını tuttuğu anlaşılan Dersaadet gazetesinde çıkan bir yazıda Yusuf Ziya'ya tertip edilen oyun edebî bir eğlence, komedi şeklinde değerlendirilir. (Bkz. "Edebî Bir Mudhike", Dersaadet, nr. 97, 20 Teşrinievvel (Ekim) 1920). Yahya Kemal'in fakültedeki öğrencilerinden Mustafa Nihad (Özön)'ün yine aynı gazetede, Yusuf Ziya'ya hitaben aynı başlıkla çıkan yazısında ise konu hakkında oldukça 
Kendisine oynanan bu oyun karşısında çok zor duruma düştüğü anlaşılan Yusuf Ziya, Yahya Kemal'in Akşam'da yayınlanan "Mektup"una cevap niteliğinde olarak Alemdar gazetesinde yazdığı yazıda kendisini savunmak adına şair hakkında o dönemde dile getirilen eleştirileri tekrar etmekle yetinir: 1912'de Paris'ten döndükten sonra edebiyat çevrelerinde kendisi etrafında büyük beklenti oluşmasına rağmen şairin bu beklentiyi boşa çıkarması, az şiir yazması eleştirilerinin odak noktasıdır. Hemen söyleyelim ki Cumhuriyet döneminde de dile getirilecek olan bu eleştirilerin özünü şairin "mükemmeliyetçi" bir şiir anlayışıyla hareket etmesi oluştursa da Yahya Kemal estetiğinde bu durumun karşılığı hâliyle yoktur. Dolayısıyla Yusuf Ziya'nın bu eleştirileri tekrar gündeme getirerek düştüğü zor durumdan kurtulmaya çalıştığı açıktır. Bununla beraber bu olaydan şahsı adına bir ders çıkardığını da açık yüreklilikle ifade etmesi dikkat çekicidir: Yazısının sonunda, Yahya Kemal'in Fransız şairlerinden intihal yaptığı yolunda kendisine ulaştırılan ve kendisini müşkül bir duruma sokan metinden alıntıları okuyucuyla paylaşarak, ünlü polisiye yazarı Arthur Conan Doyle'un romanlarındaki entrikaları aratmayacak derecede tertip edilen bu oyunun kendisi açısından bir ders niteliği taşıdığını itiraf eder ve bundan sonra daha dikkatli olacağının altını çizer. ${ }^{10}$

Yusuf Ziya'nın Yahya Kemal'e duyduğu kırgınlığın hatta kızgınlığın bu satırlarla sınırlı kalmadığını görüyoruz. Şairin daha sonra kaleme alacağı Portreler ${ }^{11}$ kitabında Yahya Kemal'le ilgili yaptığı ağır değerlendirmelerde yukarıda ele aldığımız hadisenin büyük payı olduğunu düşünebiliriz. Nitekim Yahya Kemal vefat ettikten sonra yapılan özel hayat kaynaklı bu değerlendirmeler Yahya Kemal eleştirisi söz konusu olduğunda özellikle popüler kültürde dikkate alınmaya devam etmektedir.

\section{Yahya Kemal ve Akşam Gazetesi}

Sözünü ettiğimiz yazıların Yahya Kemal'e ait olduğunu gösteren en önemli kriterlerden birisi de bir dönem Akşam gazetesinin ortaklarından olan Falih Rıfkı Atay'ın ifadeleridir. Falih Rıfkı, Mütareke dönemi hatıralarını anlattığı "Mondros" yazısında 1918 başlarında çıkmaya başlayan Akşam gazetesinin Mondros Mütarekesi'nden sonra şirketleşmeye gittiğini ve ortaklar aradığını, kendisiyle beraber başta Yahya Kemal'in de gazeteye ortak olacağını ancak şairin sonradan vazgeçtiğini söyler. ${ }^{12} \mathrm{O}$ dönemde Falih Rıfkı ile arası gayet

ayrıntılı bilgiler vardır (Bkz. "Edebî Bir Mudhike”, nr. 100, 23 Teşrinievvel (Ekim) 1920, s. 3). O dönemde Yahya Kemal'e yakınlığıyla bilinen Mustafa Nihad'ın yazısı mahiyeti itibariyle içeriden, yani bu edebiyat olayının mürettiplerinden birisi tarafından yazıldığı hissini uyandırmaktadır. Bu ise işin içinde Yahya Kemal'in de olduğu, öğrencilerin en azından onun onayıyla hareket ettiği yönündeki kanaatimizi güçlendirmektedir.

10 Yusuf Ziya'ya göre bu yaşananların özeti şudur: "Yalnız bir şey kazandık ki 'Conan Doyle'un romanlarındaki zabıta entrikalarını andıran bu usul-ı hareketin edebiyat sahasına da mahirane tatbik edilebileceğini öğrenmektir. Bu vukuf ile bundan sonra gözümüzü daha iyi açacağız." (Bkz. "Hücum Karşısında-2", Alemdar, nr. 2958-658, 23 Teşrinievvel 1920, s. 3).

11 Yusuf Ziya Ortaç, Portreler, "Yahya Kemal”, İstanbul 1960, s. 137-141.

12 "O sırada Akşam gazetesinin bir şirket yapmak istediğini işitiyordum. Gazete Necmeddin Sadık'ın, Kâzım Şinasi'nin ve Ali Naci'nin idi. Yeni şirkette benim, Yahya Kemal'in, Fazıl Ahmet'in ve Rıfat Müeyyet'in hisselerimiz olacaktı. Nihayet Yahya Kemal, Fazıl Ahmet aradan çıktılar. Biz dört kişi avuç kadar mütareke 
iyi olan Yahya Kemal ${ }^{13}$ gazeteye ortak olmamakla beraber yazı vererek Akşam'a katkıda bulunmuştur. ${ }^{14}$ Ağırlıklı olarak 1920 yılında yazılan bu yazıların büyük kısmının ** işaretiyle neşredildiğine inanıyoruz. Şunu da hemen belirtmek gerekir ki Yahya Kemal bu konuda tek değildir. İstanbul'da Millî Mücadele'yi destekleyen gazetelerden birisi olan ve bu yüzden Damat Ferit hükûmeti tarafından takip edilen $A$ kşam'da neşredilen yazıların çoğunda imza yerine bazen" * "bazen" ** "bazen de "*** "işaretleri kullanılmıştır. Nitekim 1920 yılının yaz aylarında üç ay hapis yatan Falih Rıfkı'nın pek çok yazısı da hapisten sonra bir müddet bu türlü çıkmıştır. Bununla beraber Akşam gazetesinde ** işaretiyle neşredilen bütün yazıların Yahya Kemal'e ait olduğunu düşünmek mümkün değildir. Çünkü bu yazılardan bazıları Yahya Kemal'in bildiğimiz konu yelpazesinin ve üslubunun dışında yazılardır. Bazıları da Avrupa'dan gönderilmiştir. Dolayısıyla Yahya Kemal'e ait olduğunu düşündüğümüz ** imzalı yazıları tespit ederken meseleye etraflıca baktığımızı ve zorlandığımızı ekleyelim.

Aralık 1920 tarihinde Akşam'da bir müddet başyazarlık yapan şair, "Şarka Destek", "Tevekkül", "Insanlara ve Mermerlere Merhamet", "Bir Vakıf" ile "Saatimiz Geri" başlıklarını taşıyan ve 16-21 Aralık 1920 tarihlerinde yayınlanan bu yazılarda açıkça "Yahya Kemal" imzasını kullanmıştır. ${ }^{15}$ Ancak yine Akşam gazetesinin 15 Aralık 1920 tarihli birinci sayfasında yer alan ve imza yerine tıpkı daha sonra Illeri'de yazacağı bazı yazılarda olduğu gibi ** işareti bulunan "Iki Mübariz Ruh" yazısının da gerek içerik gerekse üslup açısından diğerleriyle paralellik gösterdiği için Yahya Kemal tarafından yazıldığını düşünüyoruz. Ayrıca bu yazının Akşam'da Yahya Kemal imzasıyla yazdığı yazıdan bir gün önce yazıımış olması da bu görüşümüzü kuvvetlendirmektedir.

Yahya Kemal yazılarında imza yerine ** işareti koyma tavrını Akşam'dan sonra yazdığı Illeri gazetesinde de sürdürmüştür. Şairin Şubat-Mart 1921 tarihlerinde Illeri gazetesinde yazdığı başmakalelerin çoğu bu nevidendir. 1921 Şubat ayında neşredilen "Bebek Şamandırası" ve "Siyasîler" başlıklı yazılarında "Yahya Kemal" imzasını kullanmış, sonrasında aynı günlerde aynı gazetede yazdığı "Tecrübe ve Hüküm”, “Onun Sesi”, "Bir Düşünce”, "Tûl-i Emel”, "iki Yol”, "Yuvaya Dönüş" ve "Bir Tekzip" yazılarında ise imza yerine ** işaretini tercih etmiştir. Sonuna ** konulan bu yazılar daha sonra Nihad Sami Banarlı tarafından Eğil Dağlar kitabına alınmıştır.

Akşam'ını çıkarmaya başladık." (Falih Rıfkı Atay, "Mondros", Eski Saat, Yeni Baskı, Ankara 1998, s. 66-67).

13 Sonraları araları açılacak olan Yahya Kemal ile Falih Rıfkı'nın savaş yıllarında ve Mütareke'nin başlarında oldukça sıkı dost olduklarını görüyoruz. Hatta Yahya Kemal bu dönemde ara sıra Falih Rıfkı'nın Saraçhanebaşı'ndaki evinde kalmaktadır. Hatıralarından öğrendiğimize göre Yahya Kemal, İstanbul'un 16 Mart 1920 tarihinde İngilizler tarafından işgal edildiği gün Falih Rıfkı'nın misafiridir. (Yahya Kemal, "16 Mart", Tarih Musahabeleri, II. Baskı, İstanbul 1991, s. 41-42).

14 Falih Rıfkı́nın Akşam gazetesinin bir dönemiyle ilgili aşağıdaki ifadesi özellikle edebiyat tarihimiz açısından önemli olan ve Akşam'da yayınlanan pek çok yazının kimler tarafından yazıldığı problemiyle bizi baş başa bırakmaktadır. "Akşam'da ilk günün fıkraları imzasızdır. Çünkü herkes yazardı. Bir aralık Yahya Kemal, ben birlikte birkaç fıkra yazdık." Age, s. 67.

15 Sözünü ettiğimiz bu yazılar Adnan Akgün tarafından yeni yazıya çevrilerek yayınlanmıştır. ("Yahya Kemal'in Kitaplarına Girmemiş Yazıları", Yahya Kemal Enstitüsü Mecmuası III, İstanbul 1988, s. 94-107). 


\section{Yazılarla İlgili Kısa Notlar}

Yahya Kemal'e ait olduğunu düşündüğümüz ve işin tabiatı gereği bu konuda her türlü değerlendirmeye açık olduğumuz yazılara gelince; bunlardan ilki Akşam gazetesinde "Genç ve Yeni" başlığıyla 24 Eylül 1920 tarihinde neşredilmiştir. Bu yazı Yusuf Ziya ve arkadaşlarının, aralarında Yahya Kemal'in de bulunduğu şairler grubuna açtıkları kampanyada Yahya Kemal cephesinden verilen ilk cevap niteliğini taşımaktadır. Yeni karşısında her zaman ihtiyatlı olduğunu bildiğimiz ${ }^{16}$ Yahya Kemal bu yazısında gazete ve dergilerdeki isim bolluğuna dikkat çekerek bu durumun edebiyat ve okur açısından menfi taraflarına işaret etmektedir. "Yirmi beş sene ancak bir neslin inkişafına müsait bir devre addolunurken bizde yirmi beş senede belki birbiri arkasından on nesil türedi" diyen şair kendilerini yetiştirmeden, aceleyle çok erken yaşta gazete ve dergi sütunlarında boy gösteren şairlerin önceki neslin ağırbaşlı ediplerine alışmış halk tarafından "çocuk" olarak nitelendirildiklerini belirtir. Modern zamanların eğilimine uyup moda tabirle "Genç ve Yeni" etiketiyle ortaya çıkan isim ve eserlerin bolluğuna rağmen halk bunlara iltifat etmemekte, hürmet göstermemektedir. Bunun sebebi ise halkın edebî zevk bakımından yeni şairlerden "daha yüksek bir seviyede" bulunmasıdır. Neticede ortalama bir beğeni seviyesine hitap etmeyen bu eserler halkta edebiyata karşı "tiksinme" uyandırmaktadır. Yahya Kemal'e göre modayı esas alan gelip geçici eğilimlerin ortaya çıkardığı bu olumsuz manzara karşısında genç şair ve yazarların yapması gereken şey modanın cazibesine kapılmamak, kendisini yetiştirmektir. Çünkü "Bir milletin tahassüsü ve tefekkürü ancak rüşte ermiş mütehassıs ve mütefekkirlerin eserleri ile doyar."

"Güzel Yazılar" (nr. 726, 1 Ekim 1920) başlığını taşıyan yazı ise sultanîlerde edebiyat öğretmenliği yapan Süleyman Şevket Bey'in aynı adla tertip ettiği antolojiyi konu edinmektedir. Yahya Kemal yazısında böyle bir gayreti alkışlamakla beraber Süleyman Şevket Bey'in antolojide yer alan şiir ve düzyazıların seçiminde dikkatsiz davrandığı fikrindedir. Yeniye mesafeyle yaklaşan, edebiyatı bir bütün olarak değerlendiren ve o günlerde sık sık dile getirilen "Avrupalılaşmazdan evvelki edebî parçalarla yeni neslin çocuklarını terbiye edemeyiz" düşüncesinin karşısında olan Yahya Kemal'e göre bir milletin edebiyatını son yıllarda verilmiş, henüz tenkit süzgecinden geçmemiş eserlerden hareketle tanımlamaya çalışmak yanlıştır. Antolojide yer alan ürünlerin "onda dokuzu"nu son yıllarda gazete ve mecmualarında yayınlanmış eserler arasından seçen, bunu yaparken "bugünkü Avrupa kafasıyla" hareket etmeyen Süleyman Şevket Bey de "müntahabât kitaplarından yedi yüz senelik Türk nesir ve nazmını kov[mak] ve Türk edebiyatını bu son zavallı devrimizin yazılarına bir inhisar gibi bahşe[tmek]" yanlışına düşmüştür.

Yahya Kemal'in antolojinin başarısızlığına örnek olarak üzerinde durduğu örnek metnin ise yaklaşık bir yıl önce "Viranbağ” şiirini eleştiren Ali Canip [Yöntem]'e ait olması ise dikkat çekicidir. $^{17}$

16 Eskiyle tamamen irtibatını koparmış "yeni"ye daima kuşkulu bakmış olan Yahya Kemal'in bu konuda yazdığı bazı yazılara örnek için bkz. "Düşünceler", Edebiyata Dair, V. Baskı, İstanbul, 2005, s. 45-47; "Sade Bir Görüş", s. 51-58).

17 Yahya Kemal'e ait olduğunu düşündüğümüz bu yazının kendisine daha önce Ali Canip ve Celâl Sahir 
“Edebiyatta Münakaşa” yazısı (nr. 730, 5 Ekim 1920) Tanzimat sonrasında ortaya çıkan ve hâlihazırda devam eden dil ve gramer temelli tenkit anlayışının eleştirisidir. Zaman zaman kendisi de dil konusunda eleştiriye uğrayan şair, fikirden ve ilimden yoksun, şahsî meselelerin öne çıktığı bu tarz tenkit anlayışının "inkırâz" devirlerine mahsus olduğunu düşünür ve edebiyatın gelişimine hiçbir katkı yapmadığını savunur. Yazı ele aldığı konu açısından bir bakıma "Genç ve Yeni" ile "Güzel Yazılar"ın devamı niteliğindedir.

10 Ekim 1920 tarihinde neşredilen "Edebiyatta Cehalet" başlıklı yazı ise Yusuf Ziya ve arkadaşlarının tepkisini çeken ve yukarıda sözünü ettiğimiz tartışmayı başlatan, hatta Yahya Kemal ve Cenap Şahabeddin'in tarafını tutan Dârülfünûn gençlerinin Yusuf Ziya'ya oynadıkları oyuna ilham veren yazı olarak öne çıkmaktadır. Edebiyatta cehalet ile iftihar etmenin felsefî arka planına vurgu yapan, bunun büyük şairlere ve sanatkârlara mahsus bir tavır olduğunu dile getiren Yahya Kemal, "Edebiyatta cehaletin şerefini, kitaplardan hayata, o renklerden tabiata rücû etmeyi şiar edinen son asır Frenk şairleri ilân ettiler. Bu şiarı bizim şiirimize Abdülhak Hâmid nakletti." diyerek bir anlamda hayattan ve tabiattan ilham alan romantiklere gönderme yapar. Şaire göre, kitaplarda anlatılan bilgiye güvenmeme, önceki bilgileri reddetme, hayatı bizzat bireysel tecrübenin ışığında öğrenme ve sanata aktarma anlayışının sonucu olarak özellikle bazı romantiklerin sıklıkla dile getirdiği cehaletle iftihar etme yaklaşımı Türkiye'de özellikle genç şairler tarafından yanlış anlaşılmıştır. Cehaletle övünen büyük sanatkârlar bu noktaya gelene kadar çok şey okumuşlardır. Peki yeninin büyüsüne ve çekiciliğine kapılan genç şairler cehaletle iftihar eden sanatkârları ne derece tanımaktadırlar? Onların eserleri, ilham kaynakları ve dönemleri hakkında yeterince bilgi sahibi olduklarını söylemek mümkün müdür? “Nedim'in Arapça, Nefî́nin Farisî bildiği kadar, örneği Garp olan bugünkü nesil Fransızca biliyor ve Garp âlemini ihata edebiliyor mu?"Yahya Kemal'in yazı boyunca bazen alttan alta bazen de açıkça sorduğu bu sorulara verdiği cevap elbette olumsuzdur. Çünkü her bakımdan eksik yetişen ve kendi tarihini bilmeyen gençler ilim irfan yönüyle reddettikleri Divan şairlerinin çok gerisindedirler. Yazının sonunda ise Yusuf Ziya ve arkadaşlarına hece üzerinden getirdiği eleştiri oldukça dikkat çekicidir: "O kadar sade-dil görünen Yunus Emre'nin hece vezninde yazdığına bakmamalı: Onun hece veznindeki felsefe ve istihzasını bugünkü şairlerimiz heceleyemezler bile." Özellikle bu son cümlenin heceyle şiir yazan Yusuf Ziya ve arkadaşlarını son derece öfkelendirdiği açıktır.

tarafından yöneltilen eleştirilere bir cevap olarak yazıldığını düşünüyoruz. Ali Canip, Nedim mecmuasında (nr. 5, 13 Şubat 1919, s. 66-67. Ayrıca bkz. Prof. Ali Canip Yöntem'in Yeni Türk Edebiyatı Üzerine Makaleleri, Haz. Ahmet Sevgi-Mustafa Özcan, Konya 2005, s. 66-67) yazdığı "Yeni Vezinde İlk Şiir” başlıklı bir yazıda "Viranbağ" şiirini, "mantığa, fikre, hatta akıl ve izana" aykırı bulur ve Yahya Kemal ile alay eder. Yahya Kemal ise yukarıda ele aldığımız yazısında Ali Canip'in antolojide yer alan "Gurub" (Güzel Yazılar, C. 1, İstanbul 1920, s. 105) şiirini "bir acemi karalaması" şeklinde değerlendirir ve böyle bir metni kitabına aldığı için Süleyman Şevket Bey'i eleştirir. Yahya Kemal, yazının sonunda yer alan "Hamiş"te ise antolojiden bağımsız olarak yaklaşık üç hafta önce kendisini eleştiren ve lisanını "kusurlu” bulan Celâl Sahir'i yine lisan üzerinden hedef alır. (Bkz. Yusuf Ziya, “Celâl Sahir Bey'le Konuştum”, Alemdar, nr. 626-2926, 11 Eylül 1920). 
15 Aralık 1920'de yayınlanan "Iki Mübariz Ruh" yazısı ise Yahya Kemal'in aktüel gelişmeleri Osmanlı tarihinden hareketle değerlendirdiği siyasî nitelikli bir yazıdır. Bu yazının neşredildiği sırada Sevr felâketinden sonra düşen Damat Ferit Paşa hükûmeti yerine kurulan Tevfik Paşa hükûmeti ile Ankara hükûmeti arasında ilişkileri düzeltmeye yönelik görüşmeler başlamış, bu amaçla eski sadrazamlar Ahmet İzzet ve Salih Paşalar Anadolu'ya geçmişlerdir. Yahya Kemal ülkenin kurtuluşu yolunda İstanbul ve Ankara hükûmetlerinin izlediği yolu karşılaştırarak şöyle bir değerlendirmede bulunur: İstanbul hükûmeti Tanzimat sonrasında Reşit Paşa ile ortaya çıkan, ancak şartların değişmesiyle birlikte geçerliliğini yitiren siyaset anlayışını devam ettirmektedir. Şimdikilerin yürütmeye çalıştığı müzakereye dayalı, mücadeleden uzak siyaset anlayışında özellikle "milliyet nazariyesi" eksik olduğu için başarı şansı azdır. Hâlbuki Osmanlının kuruluş ruhuyla hareket eden Anadolu hareketi "altı asır evvel Hudavendigâr toprağında doğduğumuz gibi tekrar doğmamızdan başka selâmet yolu olmadığına inan[maktadır]." Şüphesiz iki görüş arasında ciddi bir "mübareze", çatışma ve farklılık söz konusudur. Yahya Kemal'in ise devrin şartlarından hareketle yüksek sesle dile getiremese de ülkenin kurtuluşu yolunda Anadolu hareketinin izlediği politikayı tasvip ettiği açıktır. Nitekim bu konudaki düşüncelerini Illeri gazetesinde üç hafta sonra kendi imzasıyla yazdığı "Siyasîler", üç ay sonra yazdığı "Yuvaya Dönüş" ve dört ay sonra II. İnönü Zaferi'nden sonra yazdığı "Gönül Kerestesiyle" de ${ }^{18}$ daha da geliştirecek ve özellikle son yazıda açık bir dille seslendirecektir. Başka bir deyişle artık o bundan sonra işgal İstanbul'unda Millî Mücadele'nin fikir cephesinde hareket eden bir yazar olarak Ileri, Dergâh ve Tevhid-i Efkâr'da önemli ve etkili yazılar kaleme alacaktır.

"Vatan ve Muallim Naci" (nr. 810, 24 Aralık 1920) ile "Vatan ve Abdülhak Hâmid" (nr. 812, 26 Aralık 1920) yazıları da yine dönemin ruhuna uygun olarak adı geçen iki şairin vatan duygusu etrafında yazdığı şiirlerden alıntılarla kaleme alınmış yazılardır. Bunlardan birincisinde yer alan Muallim Naci'nin "Ayrılan millet ittihâdından / Kessin ümmîdini murâdından" beyiti Yahya Kemal'in 9 Şubat 1921 tarihli "Siyasîler" yazısında da aynı bağlamda karşımıza çıkmaktadır.

\section{KAYNAKÇA}

Akgün, A. (1988). Yahya Kemal'in kitaplarına girmemiş yazıları. Yahya Kemal Enstitüsü Mecmuası III içinde (s. 94-107). İstanbul: İstanbul Fetih Cemiyeti Yayınları.

Atay, F. R. (1998). Mondros. Eski saat içinde (s. 66-67). Ankara: Kültür Bakanlığı Yayınları.

Beyatlı, Y. K. (2005). Düşünceler. Edebiyata dair içinde (5. bs, s. 45-47). İstanbul: İstanbul Fetih Cemiyeti Yayınları

Beyatlı, Y. K. (1921, 20 Nisan). Gönül kerestesiyle. Ileri, (nr. 1159)

18 Yahya Kemal, "Siyasîler", nr. 1092, 9 Şubat 1921; “Yuvaya Dönüş”, İleri, nr. 1132, 23 Mart 1921; “Gönül Kerestesiyle", nr. 1159, 20 Nisan 1921. 
Beyatlı, Y. K. (1991). 16 Mart. Tarih musahabeleri içinde (2. bs, s. 41-42). İstanbul: İstanbul Fetih Cemiyeti Yayınları

Beyatlı, Y. K. (2005). Sade bir görüş. Edebiyata dair içinde (5. bs, s. 51-58) İstanbul: İstanbul Fetih Cemiyeti Yayınları

Beyatlı, Y. K. (1921, 9 Şubat) Siyasîler. İleri, nr. 1092

Beyatlı, Y. K. (1921, 23 Mart). Yuvaya dönüş. Illeri, (nr. 1132)

Haşim, A. (1991). Paris görmüş bir zat. İ. Enginün ve Z. Kerman (Ed.), Ahmet Haşim-bütün eserleri III içinde (s. 117-119). İstanbul: Dergah Yayınları.

Ortaç, Y. Z. (1920, 14 Ağustos). Başlarken. Alemdar, nr. 2899-599.

Ortaç, Y. Z. (1920, 11 Eylül). Celâl Sahir Bey'le konuştum. Alemdar, (nr. 626-2926).

Ortaç, Y. Z. (1920, 16 Teşrinievvel). Hücum karşısında-1. Alemdar, (nr. 2958-658).

Ortaç, Y. Z. (1920, 23 Teşrinievvel). Hücum karşısında-2. Alemdar, (nr. 2958-658).

Ortaç, Y. Z. (1960). Yahya Kemal. Portreler içinde (s. 137-141). İstanbul: Akbaba Yayınevi.

Özön, M. N. (1920, 23 Teşrinievvel). Edebi bir mudhike. Dersaadet, (nr. 100, s. 3).

Süleyman Ş. (1991). Güzel yazılar I-II (İ. Enginün ve Z. Kerman, Ed.). İstanbul: Türk Dil Kurumu Yayınları Yöntem, A. C. (1919, 13 Şubat). Yeni vezinde ilk şiir. Nedim, (nr. 5). 


\section{METINLER}

\section{Musahabe-i Edebiyye}

\section{Genç ve Yeni}

Kemalpaşazade Said Bey'in bir mısral-Fikret ve neslinin gayesi ne idi?- Halkın muharrirlere ve edebiyata karşı bugünkü nazarı

Otuz senedir edebî sahifelerde muttasıl geçen iki kelime vardır: Genç ve yeni. Fakat her modanın bir nihayeti olduğu gibi bu genç ve yeni kelimelerinden de herkesin zevkine bir tiksinmedir ârız oluyor. Kemalpaşazade Said Bey daha Teselya harbi sıralarında:

\section{Şiir bâzîçe-i tıflâne oldu}

diye telehhüf ediyordu. O zamanın nice karileri Kemalpaşazade'nin telehhüfünü ulemâ-perestliğine verdiler. Çünkü o senelerde Fikret-Halit Ziya gençliği ufukta bir yıldız gibi parlıyordu. Bütün elebaşıları ihtiyar olan Hamîdî cemiyetten artık bezenler hep bu yıldıza bakıyordu. Ancak yegâne manevi gayesi o vakitki koskoca vatanın hudutları içinde müstakbel Türk yurdu için bir saha bulamayıp da Zeland-ı Cedîd'e giderek orada Hüseyin Cahit Bey'in meşhur hayat-ı muhayyel hikâyesinde naklettiği gibi ferih ve fahur bir İngiliz köşkü hayata geçirmek kadar pest olan o hodbin gençlik zamanla anlaşıldı ki bir yıldız değil bir ateşböceğiymiş. O zamandan beri genç ve yeni kelimeleri bu infisah devrinde malûl olduğumuz gösteriş ve hodkâmlığın şiarı oldu.

Yirmi beş senede ada tavşanı gibi bir velûdiyetle Osmanlı irfanı vire genç nesil yetiştiriyor. Her genç nesil yeni bir edebiyatın müjdeleri ile yükseğe bir hava fişengi gibi atılıyor. Yirmi beş sene ancak bir neslin inkişafına müsait bir devre addolunurken bizde yirmi beş senede belki birbiri arkasından on nesil türedi. Bugün artık edebiyatımızın gerek his gerek fikir sahasındaki havas sınıfı ekseriya sultanî mekteplerini bitirmemiş gençlerden müteşekkil bulunuyor. Fakat gençliğin bu şiddetli gınâsına bir aksülamel olmak üzere de maatteessüf amme ve halk edebiyata bir genç heveskârlığı, bir çocuk eğlencesi telakkisiyle kayıtsız kayıtsız bakıyor. En güzel eser-i edebîyi çocukların terakkisine ibzal olunan "Maşallah fena değil, aferin yetişecek bu çocukta bir şeyler var aferin, aferin pek hoşuma gitti, tüh tüh nazar değmesin." takdirleriyle karşılıyor. Görülüyor ki ammede edebiyat artık bir zaman olduğu gibi Namık Kemal ve Hâmid'lerin işi değil, bir çocuk işi olduğu kanaati de yerleşiyor. Dün edebiyata pek iyi aşina bir zat buyurdu ki:

-Canım, biz bir zaman moda olan muharrirleri sokakta, vapurda senelerce göremez hatta resimlerinden tanımaz, lâkin hayalimizde yaşatırdık. Meselâ Namık Kemal'i Magosa zindanında, Midilli mutasarrıflı̆ında, Ahmet Midhat'ı Babıali caddesinin matbaalarında adeta fevkalbeşer birer mahlûk gibi tahayyül 
eder, severdik. Millet hayalinde muharrirlerine birer heykel varlığı verir, onları kendinden yüksek mahlûklar tasavvur ederdi. Bugünkü muharrirlere muhayyilemizde böyle bir şekil vermek şöyle dursun lâyıkıyla ehemmiyet bile veremiyoruz. Bana öyle geliyor ki onlar âdemdi şimdikiler çocukturlar.

Biz cevap verdik:

-Fakat Magosa zindanında Namık Kemal Bey veya Babıali matbaalarında Midhat Efendi o zaman yirmi beşinde, otuzunda gençlerdi. Şimdiki genç muharrirlerimizin bu kadar yaşlıları var.

-Öyleyse bu yaştan ziyade baştan gelen bir fark olacak ki genç neslin aleyhinde daha fena bir hükmü haizdir.

Evet maatteessüf pek doğru bir görüş... Daha yirmi sene evvel bizde halk muharrirleri, Vecihî'nin, Hüseyin Rahmi'nin resimlerini tecessüsle arar, terceme-i hâllerini sorar, araştırır hatta onların hayatına dair efsaneler icat ederdi. Bugünkü muharrirler resimlerini halkın yüzüne istemediği hâlde muttasıl projektör gibi tuttukları hâlde bile yine gözlerini kamaştıramıyor, tecessüsünü tahrik etmiyor, kendilerini halka mâl ettiremiyorlar.

Bir defa bunun sebebi aşikârdır: Halk öyle vezin, terkipli lisan ve terkipsiz lisan patırtılarından bir şey anlamıyor. Kendini Vecihî gibi ağlatacak, Hüseyin Rahmi gibi güldürecek, Midhat Efendi gibi meraklandıracak muharrirler istiyor. Bu muharrirlerin hakikaten vezin ve lisan münakaşaları aralarında geçerdi. Halka verdikleri asıl deha ve zekâlarının meyvesi idi ve bu muharrirler zamanlarına göre ammelerinden yüksektiler ve ammeyi kendilerine yükseltiyorlardı. Şimdi kaide ber-aks: Kariler genç nesil muharrirlerinden daha yüksek bir seviyede bulunuyor ve yüksek bir seviyeden daha dûn bir seviyeye baktığı için de hayran olmuyor. Genç neslin yazılarında güzel bir şey gördüğü zaman "Maşallah maşallah fena değil!" diyor, nev-hevesleri tergib eder yollu pederâne iltifatlar bezlediyor.

Bizde son senelerde yazıları her gazeteye kabul olunan bir edip olmak Dârülfünûn'da ikmâl ve tahsil etmekten çok kolay bir iş oldu. Bir millette yirmi yaşında dahilerin yetişmesi müsteb'ad değildir, fakat binde birdir. Üdeba cumhurunun yüzde doksan dokuzunu hepsi rüşte ermiş irfanı kuvvetli, zevki tok, sözü yerinde istidatlılar teşkil eder. Bizde modadan düştükleri haber verilen Cenap Şahabettin Bey, Halit Ziya Bey henüz ellilik, elli beşlik ediplerdir. Hâlbuki Fransa'da genç neslin en mümtaz şairi Henri de Régnier, en mümtaz nâsiri Maurice Barrès bugün ellisini çoktan geçmiş muharrirlerdir ve bugün için hâlâ yeni addedilirler. Yirmi beş sene addolunan bir devir bu büyük insanların eserine nüfuza bittabi kifayet etmedi.

Halkın sözü hakkın sözüdür. Bugün bizde edebiyata karşı yukarıda şerh ettiğimiz gibi bir hürmetsizlik, edebiyatı bir nev-heves işi telakki ediş mahsus oluyor. Bu telakkinin ise tamamiyle edebiyatın henüz irfanı belirmemiş gençlerin elinde bulunmasından geldiğine 
şüphe var mı? Gençler aldanıyorlar: Mecmualarda, gazetelerde muttasıl geçen isimleri ve resimleriyle bu milleti doyuramazlar. Bir milletin tahassüsü ve tefekkürü ancak rüşte ermiş mütehassıs ve mütefekkirlerin eserleri ile doyar. Her moda gibi gençliğin ve yeniliğin de modası geçti, hatta bezginlik had bir derecededir.

Yirmi beş sene moda yeter. Artık edebiyatın hakiki heyecanlarına, hislerine, fikirlerine muhtaciz.

(Akşam, nr. 719, 24 Eylül 1920, s. 3)

\section{Edebî Sütun}

\section{Güzel Yazılar}

Müellifi: Süleyman Şevket, iki cildi intişar etmiştir.

Süleyman Şevket Bey ömrünü sultanîlerde çocuklarımızın edebî zevklerini terbiye etmeye vakfetmiş muhterem hocalardandır. Süleyman Şevket Bey son günlerde Güzel Yazılar unvanıyla bir silsile-i müntahabât neşrediyor. Çocuklarımız için Matbaa-ı Âmirede zamana göre epeyce iyi basılmış iki cildini okuduk.

Sultan Abdülaziz'den evvel çıkan Türkçe müntahabât kitaplarına güldeste derlerdi. Acaba bu unvan niçin şimdi metruk bulunuyor? Güldeste lügatte "antoloji" demektir. Avrupalılığa çok bigâne olduğumuz zamanlarda acaba bu tercüme kime aittir? Son devirde "antoloji"lere "müntahabât" unvanı veriliyor. Süleyman Şevket Bey bu unvanı da bırakarak daha hür bir endişe ile eserine Güzel Yazılar adını vermiş. Bir parça sert bir tasdik manasını ihtiva eden bu unvan altındaki eserleri dikkatle tetkik ettik. Onda dokuzu son senelerin gazete ve mecmualarında gördüğümüz mahsulü idi. Herhangi bir muharrir Güzel Yazılar unvanlı serbest bir eser neşretseydi hiçbir münekkit intihabını pek fazla hırpalayamazdı, fakat bir muallimin sultanîlerimizdeki çocuklara göstermek üzere topladığı parçalar birçok nokta-i nazardan alakadar eder.

Son on senede bir itiyattır hâsıl oldu: Müntahabât kitapları çıkaranlar kitaplarını hep son zamanların edebî parçalarıyla dolduruyorlar. Eserlerinin üzerinde bu zamanın şu zümresine ait yazılar olduğu gibi bir kayıt koymayan bu müntahibler bize öyle geliyor ki umum Türk edebiyatına karşı biraz kayıtsız davranıyorlar. Hatta bu kayıtsızlıkta eslafa karşı müsaade edilemez bir tecahül, bir laubalilik var. Bu bahsi fazla eşelemeyelim. Bazı [edebiyat] şinaslarımız müfrit bir Avrupa-perestlikle malûl olduklarından diyorlar ki: "Avrupalılaşmazdan evvelki edebî parçalarla yeni neslin çocuklarını terbiye edemeyiz, tabiî ki mekteplerde Acemaşiran faslı yahut da karcığar peşreviyle musiki terbiyesi veremeyeceğimiz gibi. Fransızlar vakıa klasik müelliflerini pek ziyade ihtimamla tedris ederlermiş. Fakat o Fransız klasikleri yeni ahlak ve yeni terbiye ile zıt değillermiş." Bir kelime 
ile cevap verelim: Bu iddia şiddetle götürüdür ve Türk edebiyatını yeni bir kafa ile yeniden yeniye tetkik etmemekten hâsıl olmuş bir iddiadır. Ziya Paşa'nın Harâbât'ı ile bıraktığı eserle edebiyat okutmak belki bugünkü ahlak ve bugünkü terbiye ile telif edilemez. Ancak Ziya Paşa'nın Harâbât'ı isterse bir umman olsun yine Türk edebiyatında yalnız bir çığırdır. O zamandan beri edebiyat muallimlerimiz Türk edebiyatını bugünkü Avrupa kafasıyla yeni baştan bir arayıp taradılar mı ki ceffelkalem müntahabât kitaplarından yedi yüz senelik Türk nesir ve nazmını kovuyor ve Türk edebiyatını bu son zavallı devrimizin yazılarına bir inhisar gibi bahşediyorlar. Dünyada bizden başka bir millet yoktur ki mekteplerindeki müntahabât kitapları ancak son neslin eserlerine makes olsun. Edebiyat ve tarih dersleri Türk gençlerini Türk yetiştirebilecek yegâne derslerdir. Halit Ziya Bey'den ötesini görmemek maatteessüf bugünkü neslin yalnız gençlerinin değil, muallimlerinin, ediplerinin, şairlerinin de şiarı oldu. Bu kadar köksüz bir nesil Avrupa ve Amerika'nın hiçbir milletinde görülemez.

Süleyman Şevket Bey'in pek cömert bir ihtimamla topladığı Güzel Yazılar da maatteessüf bu söylediğimiz kusurla malûl. İki kitabındaki muhteviyatın da onda dokuzu hemen hemen dünkü edebî parçalardan müteşekkil bulunuyor. Hatta içlerinde henüz matbaa mürekkebi kurumamış şaheserler bile vardır! Vakıa pek iyi idrak ediyoruz ki Süleyman Şevket Bey sultanînin altıncı ve yedinci sınıflarındaki çocuklarımıza Türk vatanını sevdirecek parçalar intihabıyla dar bir dairede hareket etmiş, fakat bu parçalar yalnız şu son beş on senenin içinde mi aranır? Eski muharrirlerimizden yalnız Evliya Çelebi'de Süleyman Şevket Bey'in iki kitabını doyuracak kadar güzel ve zengin ve pek özlü parçalar yok mu? Eslafın heceden ve aruzdan; hele sade nesirden o kadar nefis eserleri nerede? Biraz evvel de dediğimiz gibi maatteessüf yalnız Süleyman Şevket Bey değil, bütün müntahabât kitapları neşredenler, henüz Türk edebiyatının nâ-mer'î ufuklarını bir türlü aşamadılar.

Son zamanların bir farikası da henüz çıkmış eserleri edebiyat muhitinin şöyle böyle bir dikkatiyle şaheser ilân edişidir. Bazı müntahibler hatta edebiyat muhitinin de henüz farkına varmadığı eserleri devşirerek müntahab bir parça gibi kitaplarına koyuyor, edebiyat mütehassısı olanları bile şaşırtıyorlar. Hiç müellif ismi zikretmeksizin Süleyman Şevket Bey'in bu Güzel Yazılar'ına ithal edilen bir parçayı olduğu gibi istinsah ediyoruz:

Ufukta günün boynu büküldü;

Şimdi İstanbul solgun bir güldü.

Öksüz kalma bir parça dökül,

Solgun gül! Solgun gül!

Güzel Marmara menekşelendin!

Daha bir saat önce pek şendin,

Bahardın, gülşendin!

Ey güzel İstanbul,

Ey şiirin yuvası: Gül neşe bul! 
Bize bir acemi karalaması gibi görünen bu eser bilmediğimiz, anlayamadığımız, duyamadığımız bir güzelliği muhtevi ise demek ki son derece nev'i şahsına münhasır bir cevherdir. Fakat hiç zannetmiyorum. Son mısraında çok bariz bir kavaid hatası göze çarpan bu manzume belli ki lisanı bile dürüst olmayan kudretsiz bir muharririn elinden çıkmış:

\section{Ey şiirin yuvası: Gül neşe bul!}

Yani Türkçemizde "Neşelen, neşeyâb ol" demek olacak. "Neşe bul"un gayet sırıtkan bir Frenkçe emr-i hazır olduğu dün gibi aşikâr. Fazla olarak bu da yanlış, çünkü daha münasip bir yanlış olabilmesi için neşeni bul olmalıydı. Kavaid hatası olan bir eseri Frenk çocuklarına mahsus kitaplarda görmek güçtür.

$\mathrm{Bu}$ manzumeyi bir misal olarak aldık, ıtnap etmek istemiyoruz. Yoksa Süleyman Şevket Bey'in iki kitabında da buna muadil nesir ve nazımdan daha çok sû-i intihâblar var. Müntahibin ilgi ve teveccühkârlığı galip olduğu için en nev-şüküfte muharrirlerin şöyle böyle eserlerini bile kitabında yer bulmaktan mahrum bırakmamış. Fakat bu hüsn-i niyette yumuşak olmaktan ziyade sert olan adalet namına hüsn-i intihabı temin edememiş. Bugüne göre bile değeri meşkûk parçalar acaba beş on sene sonra bizzat müellife nasıl görünür? Evet bir güzel eserin kıymetini ölçen nedir? Müntahabât müntahibin zevki mi, edebiyat ammesinin kısmen veya umumen takdiri mi? Hiç edebiyata aşina olmayan karilerin dikkati mi, yoksa en iyi musaffí olan zaman mı? Demiyoruz ki bir eserin muhakkak değeri ancak zamanın müruru ile anlaşılır. Bazı yazılar olur ki ammenin, halkın hiç su götürmeyen samimi bir heyecanıyla daha hîn-i intişarında bir şaheser olarak telâkki olunur. Ancak böyle yazılar ne kadar azdır. Bunun için bir müntahib intihabını daha iyi kollamak ümniyesiyle zamanın tasfiyesine yahut da umumîzevkin tasdikine ciddi bir ehemmiyet verir. Burada biz ne söylesek fazladır. Hem bu kadar dûr u dırâz tefekküre ne lüzum var. Iş̧te daima okuduğumuz Fransız mektep müntahabât kitapları meydanda. O kitaplarda görüyoruz ki bugün yetmiş yaşına girmiş Anatole France'ların, Pierre Loti'lerin eserleri bile ya birkaç sayfa buluyor ya bulamıyor. Fransız liselerinde bir muallim en ileri gelmiş muasırlardan bile biraz ürkerek bahseder. Çünkü mektepte edebî terbiye kendi zevkine has bir eğlence değildir. Bizim müntahabât kitaplarımızda ise ammece eserleri değil, henüz ismi bile meçhul gençler pek münasip bir mevki buluyorlar, hatta müntahabât kitapları sebeb-i şöhretleri oluyor. Bu satırları ikmal ederken yine tekrar edelim ki bizi asıl mustarip eden cihet yukarıda işaret ettiğimiz gibi Türk çocuğuna, Türk edebiyatını, Türk âlemini, Türk hatıralarını yedi yüz seneyi nazır geniş bir taraçadan göstermeyip de on seneye -hem de tarihimizin ibdâ' kuvveti namına on senesinenazır bir pencereden göstermekteki zühûldür.

$* * *$

Hamiş: Celâl Sahir Bey'in son perşembe çıkan "edebiyat lakırdılarını" lakırdı diye değil ciddi okuduk. Zannediyoruz ki asıl mühim fikirleri nahvini ve manasını bir türlü söktüremediğimiz bu cümlelerinde idi."Bir gün bir Edebiyat-ı Cedîde üstadı onun fenerine bir kahraman sopa ilâve ederek aslına hiç benzemeyen bir zamane Diyojen'i şekline girer 
ve elindeki fenere rağmen muarızının ellerini ayaklarından tefrik edemeyecek kadar ma'yûb bir zarafet gösterir."

Yeni Türkçenin aynı zamanda pek kavaid mutaassıbı olan müdafii Celâl Sahir Bey'i Cenap Şahabettin Bey'e bu kavaid eslihâsıyla hücum ederken biraz tehlikede görüyoruz.

(Akşam, nr. 726, 1 Teşrinievvel [Ekim] 1336, s. 3)

\section{Edebî Sütun}

\section{Edebiyatta Münakaşa}

Eski Osmanlı şairleri ne şahane insanlarmış. En nadir eski kitaplarımızı toplayan bir dostun evinde üç yüz senelik, nefasetini anlatmak için enfes kelimesi az el yazması bir müntahabât divanı gördük. Bir müntahabât divanı ki Zati'den Baki'ye kadar en eski Türk şairlerinin müntahab şiirlerini, başta terceme-i hâlleri en başta da resimlerini muhtevi. Evet resimlerini muhtevi, tıpkı bugün Avrupa'da yapıldığı gibi. Meğer üç yüz sene evveline kadar bizde birçok nefis eserler gibi müntahabât mecmuaları da resimli çıkarmış. Bu nefis el yazması mecmuaya gözlerimiz kamaşmış uzun uzun baktık. Her şair şiirine benzeyen bir çimenlikte millî tarzda oturmuş, kimi bir derenin akışına bakıyor, kimi bir servi altında düşünüyor, kimi bir gül ağacının dibinde elinde bir şarap kadehi ile gülümsüyor, kimi de gözlerini kapayıp ledünnî bir âleme dalmış. Her biri kendi âleminde bir padişah gibi yaşıyor.

Her kimse kendi âleminin padişahıdır

meselindeki manayı bu nefis mecmuaya bakarken ayan beyan gördük. Bu koca insanlar bugün bizim edebiyat dediğimiz hırıltı, zırıltı, mırıltı faslı nedir bilmemişler.

Her nev'i yazıları bol olan Osmanlı edebiyatı münakaşa ve güft u gûdan nispeten çok azadedir. Eski şairlerin divanlarında arada sırada muasırlarına attıkları okların ucu görülüyorsa da hiçbir zaman şairler müşatemesi bütün bir devirde asıl şiire, fikre zerre tagallüb ederek sahib-kırân kesilmemiş. Münakaşanın şiire tagallübü son elli senenin cilvelerindendir.

İstanbul'da gazeteciliğin teessüsü nesri, nesir de fikirleri bittabi şiirden bir saf öne attığından beri edebiyatımızda bir vadi peyda oldu: Münakaşa. Eğer felsefemiz çok zengin, ilmimiz çok filizli, sanatlarımız çok mütenevvi olsaydı bu yeni vadi halka fikirleri tamir etmek gibi bir vazifeyle çok faydalı olurdu. Heyhat, bin kere heyhat! Münakaşa eski ilham menbalarının kuruyup yeni fikirlerin henüz tecelli edemediği bir devrede asıl edebiyat eserlerinden daha ziyade hararetle takip olunuyor, daha ziyade alkışlanıyor. Şiiri kupkuru, romanı tamtakır, tiyatrosu çocuk mel'abesi, tarihi kekeme, tenkidi sıfır olan son seneler edebiyatının, münakaşa sahib-kırânı kesildi. Bu neslin şairleri ve muharrirleri hararetlerini 
münakaşa ile veriyor, bu neslin karileri şiirlerden, fikirlerden ziyade münakaşalardan zevk alıyor. Cenap Şahabettin Bey zühulune vereceğimiz bir cümle ile gençlere fena bir edebiyat telâkkisi telkih etti: Alkışa alkış, ıslığa ıslık! Şiirin intikamı mı nedir, bugün görüyoruz ki evvela kendileri ısıklar ortasında kaldılar.

Edebiyatımızın nüsgü pek az, bari münakaşaya ihtiyaç hissettirecek ilmimiz olsa...

Fakat evvelâ bir şüpheyi halledelim. Bütün bu münakaşalar fikrî ihtiyaçlardan mı geliyor? Bu düşünülecek bir noktadır. Eskisi gibi İstanbul meydanlarında cirit oyunları, mahallelerinde horoz dövüşleri olsaydı yahut da bu asra göre at koşuları, sandal, tayyare, bisiklet ve kotra yarışları memleketimizde de teessüs etse edebî kariler edebiyattaki kör dövüşlerine başını bile çevirmez, münakaşacılar ne alkış ne ıslık sesini işitebilirlerdi. Her milletin gençliğinde olduğu gibi bizde de gayet tabiî bir elleşip enseleşme ihtiyacı var. Bu ihtiyacı da dar hayatımızın yegâne eğlencesi olan edebiyatımızda teskin edebiliyoruz. Bu zan düşündükçe bize adeta bir hakikat gibi görünüyor. Çünkü İrfan Paşa ile Namık Kemal'in münakaşasından bugüne kadar bütün o sürekli münakaşaların neticesi meydanda. Bu vadide kalem şakırdatmaktan ne kadar muharrir şöhret kazandı? Çoğu edebiyatımıza bir habbe yadigâr bırakmadılar ve ekserisi hafızamızdan bile silindiler. Yalnız başlıca münakaşalara bir göz gezdirmek kafi.

İrfan Paşa ile Namık Kemal bir inşa ve sarf kavgası ettiler. O meşhur münakaşanın millete yegâne faydası Namık Kemal gibi yüksek bir ruhun birkaç gün evvel iştiharı oldu. Recaizade ile Muallim Naci'nin serpintisi bugüne kadar gelen kavgası onda bir zihniyet farkı ise onda dokuz cana kıyasıya nefsânî galeyanlardan ibaret değil miydi? Bugün o rakiplerin yazdıklarını ele alacak bir kari öyle meşhur bir münakaşanın bir zihniyet farkından hâsıl olmadığını birdenbire anlayamaz bile. Sait Bey'le Midhat Efendi'nin o kadar gürültülü "Klasikler" münakaşasından bu millet klasikliği değil kelimenin doğru dürüst tarifini olsun anladı mı? "Dekadanlar" münakaşasından, az çok Fransızca bilenlerine kadar bütün memleket karilerinin hafızasında kalan Frenkçe kuru bir sözdür. Hüseyin Cahit Bey'le Ali Kemal'i karşılıklı iki pehlivan eden münakaşa bir incir çekirdeği doldurmaz: Hüseyin Cahit Bey bir gün gürültülü bir savletle ispat etmiş ki Ali Kemal Bey Élysée Sarayı'nı bizzat ziyaret etmemiş, o ziyareti Figaro muhbirinin makalesinden tercüme etmiş. Bu keşiften iki tarafın taraftarları olmaz heyecanlara düştüler, fakat Türk edebiyatı ne kazandı? Cahit Bey'in Naci tilmizleri ile bütün mücadelelerinden yalnız bir beyit yadigâr kaldı:

Böyle bir herze-gû Celâl olmaz

Başını kesmedikçe lâl olmaz

Fecr-i Âti'nin daha dün cereyan eden kavgaları neye dairdi, hatırlamak bile müşkül. Belli başlı bir mevzua dair olan lisan münakaşalarına gelince, daha bugünden anlıyoruz ki o gürültüler Türkçeyi ne bir adım ileri götürmüş ne de bir adım geri.

Almış yükünü şöyle ki seyrinde halelsiz 
Türkçe, Tevfik Fikret'in ilk mısralarından beri kendi kendine kademe kademe lisan münakaşalarına hiç girmemiş, şair ve nâsirlerin gösterdiği numunelerle Türkçeleşmiş, rengarenk bir yazı nesci iken ağarmış. Bugün ne bir tarafın dediği gibi meclise "kurultay" padişaha "hakan" ne de öteki tarafın dediği gibi ciddiyete "cidd", öğle uykusuna "kaylûle" diyoruz.

Evet, elli senelik münakaşalarımız faydadan ziyade zarar verdi. Halka bir şey öğretmekten ziyade birçok gençleri kulak misafirliği göz aşinalığı ile bilgiç etti. Bugünkü gençler bir şiir, bir tiyatro, bir roman eseriyle parlamak değil, meselâ Cenap Şahabettin Bey'le bir münakaşa ucu yakalayarak şöhret kazanmak hasretini çekiyorlar.

Elli senelik münakaşalarımızdan fikirce çok şey hâsıl olmadı. Bari ahlâfın okuyabileceği gibi hararetli yazı parçaları kalsaydı.

Frenkler edebiyatta sarf, nahiv ve lisan münakaşalarının tagallüb ettiği devirlere İskenderiyecilik yani inkıraz devri derler. Eğer bugünkü Türk gençlerinin eserden ziyade münakaşaya meyillerine ifratla bakılırsa Doğu'dan ziyade bir Batı devrinde olduğumuza hükmetmek lâzım değil mi?

(Akşam, nr. 730, 5 Teşrinievvel [Ekim] 1920, s. 3)

\section{Edebiyatta Cehalet}

Edebiyatta cehaletle iftihar etmek nâ-puhtelerin gözlerini kamaştıran bir çiçektir ki ilk defa Abdülhak Hâmid'in dudaklarında açtı. Bizim gibi asırlardan beri şairi âlimle bir tutmuş Şarklı insanlar, Kurtuba'dan Kabil'e kadar, Londra'dan Hindistan cangıllarına, Paris'in gece âlemlerinden Mavera'da büyük tayfların geçtikleri geçide kadar nice iklimler üzerindeki halifeler, ilhanlar, hakanlar, renk renk ahali, ordular ve hayvanlarla temaşa ettiren bu büyük şairin cehli ile iftiharını işittiği zaman şaşırakaldılar. Bir şairin cehaletiyle iftiharı Şark'a göre ne kadar yeni bir mucizeydi! Biz Türkler ki şairle âlimi birbirinden ayırmaz ve bunca seneden beri bu iki meziyeti de âlimlerimizden vezirlerimize ve padişahlarımıza kadar her yüksek insanda mutlaka mütecelli görürdük.

Abdülhak Hâmid'in cehaletini itiraf edişi şâyi olduğu zaman inananlar da oldu, inanmayanlar da... Her vahyine olduğu gibi bu itirafına da inanan en hâr perestişkârı Abdülhalim Memduh diyar diyar gezer, Hâmid'in dehası gibi cehlini de haber verir, dinleyenleri hayrete düşürürdü. Hatta bir gün Abdülhak Hâmid Bey'e her nedense gücenen eski bir arkadaşı Abdülhalim Memduh'a der ki: “Abdülhak Hâmid'in nesi büyük şair, bir defa kara cahildir, hatta cehlini kendi bile itiraf eder, bana bir defa: Ben bir şey bilmem dedi." Arkadaşının bu sözü Abdülhak Hâmid'in kulağına gelir. Cehli ile iftihar eden büyük şair arifane bir tecahülle der ki: "Evet doğrudur. ... Bey Paris'e geldiği zaman beni gördü, dedi ki: -Acaba Ahmet Rıza Bey'in gazetesine birkaç bent yazsam Abdülhamid bana 
bir Şura-yı Devlet azalığı verir mi, ne dersiniz? Kadim arkadaşıma: - Ben bir şey bilmem! dedim."

Cehalet itiraf edilirken hele bir şairin ağzında, nefsi pek tatlı okşar, fakat isnat olunduğu vakit bir lekedir.

Edebiyatta cehaletin şerefini, kitaplardan hayata, o renklerden tabiata rücu etmeyi şiar edinen son asır Frenk şairleri ilân ettiler. Bu şiarı bizim şiirimize Abdülhak Hâmid nakletti. Nice gençler bu şiara düşüncesizce firifte oldular. Beylik edebiyattan iğrenmek genç kafaların üstünde esen bir rüzgârdır. Fakat bazı beylik hakikatler, gayeye varmak için gençlere turfanda heva vü heveslerden daha emin bir rehber olabilir. Bir millet ilmin her neviyle gıdalanmış seviye sahibi değilse, sanatta güzel eserler yaratamaz. Son devrin Türk edebiyatı dardır, çünkü manevi Türk kâinatı dardır. Shakespeare büyük şairlerin en cahili idi. Shakespeare'in cehaletini gençler büyülü bir hadise gibi görürler. Uzun bir bahse kısa yoldan girelim.

Shakespeare üç yüz sene evvel Londra'da yaşıyordu, o senelerde İngiliz irfanı en kıymetli bir fezeyân hâlinde idi. Shakespeare otuz tiyatro yazdı, bu tiyatrolardan birinin ismi "Jül Sezar"dır. Shakespeare bu eserini Latin menkıbe-nüvisi Suetonius'un "On İki Kayser" unvanlı eserinden iktibas etmiş. Eserde vaka Roma meydanlarında, Roma'nın o senelerdeki şeklinde ve ruhunda geçer. Cahil Shakespeare'den üç yüz sene sonra bugün hangi Türk şairi "Suetonius"un muhalledesinden bir faslı çıkarıp da tiyatro sahnesinde diriltebilir, demeyeceğiz, kaç şairimiz Suetonius'un o faslını şöyle bir kuş bakışı okumuştur da demeyelim, kaç şairimiz dünyada kitabı kâr-ı âlem olmuş Suetonius'un adını bilir! Daha bir hatve ileri gidelim mi? Kaç şairimiz Shakespeare'in Roma mevzulu o eserinden bu medeniyet asrında coğrafya ve tarih imtihanı geçecek kuvvettedir.

Shakespeare'in otuz kadar dramı hep böyle Yunan ve Latin muhalledeleri ve Kurun-ı Vustâ masallarından muktebes eserlerdir. Kimi Roma'da, kimi Atina'da, kimi Sicilya'da, kimi kadim Troya'da, kimi İskoçya'da, kimi Danimarka'da, kimi Mısır'da bütün bu iklimlerin birer devrinin çerçevesindedir.

Shakespeare'in eserlerinde çizdiği manevi kâinatı bir tarafa bırakırsak, yalnız coğrafya âlemi kaç şairimizin hayalinde yaşar! Shakespeare'in bizim kulaklarımıza kadar gelip de hayran olduğumuz cehaleti, iyi dikkat etmeli ki, muasırı olan feylosof "Bacon"a göredir. Bize göre değil!

Deha bir ağaçtır ki yalnız irfan toprağında kökleşir. Shakespeare İngiltere'de Rönesans güneşi uçta iken doğdu ve yazdı: İki asır evvel doğamazdı ve yazamazdı. Gençlerimizin cehaletine hayran olduğu diğer iki büyük Fransız şairi de Paul Verlaine ve Pierre Loti'dir. Şiirlerini okuyanlarımız parmakla sayılacak kadar az olan Paul Verlaine'i ilme karşı savurduğu küfürlerle her nedense ezber biliyoruz! Gençlerimiz yanılmasın için iki misal hatırlatacağız. Paul Verlaine "Fêtes Galantes" unvanlı bir şiir mecmuasında on sekizinci 
Fransız asrını bütün genç âşıkları, genç rahipleri ve karnaval temsillerini kapalı bir park içine alır ve onları o asrın nazenin lehçesiyle söyletir. Acaba kaç şairimiz bizim o asrımızı, Boğaziçi'nde bir saray bahçesinin çerçevesine alarak yaşatabilir demeyeceğiz, kaç şairimiz bizim o asrımızda İkinci Sultan Mustafa'dan, Üçüncü Sultan Selim'e kadar gelmiş geçmiş padişahlarımızı parmakla sayabilir.

Pierre Loti'ye gelince, Akademi'ye girdiği zaman söylediği nutukta, bir şey okumadığını itiraf edişi bizim Abdülhak Hâmid'in cehaleti kabilindendir. Çünkü Loti'nin Hindistan'da görüp bahsettiği menkıbeleri, Mısır'da görüp bahsettiği âsâr-ı atîkayı maatteessüf bizim bugünkü Darülfünûn müderrislerimiz bile birden bire anlayamıyor.

Edebiyatta cehaletin faziletine inanmak bize Frenklerden gelmiş bir fikir olduğu için gençlerimiz cahil-dahi örneklerini de Frenklerde görüp aldanıyor.

Eski Osmanlı şiiri çok kanlı canlı, zaman zaman çok feyezanlı idi. Çünkü eski şairlerimiz bütün İslâm kâinatının vârisi ve hârisi idiler; örnekleri olan Arap ve Acem şiirini derinden derine bildikten başka, Arabîde rubaî, Farisîde gazel söyleyebiliyorlardı; onlar kendi kâinatlarının eri idiler. Hatta dilimizin ucuna gelmiş bir mukayeseyi yapmaktan çekinmiyoruz: O yalnız içmiş ve saz dinlemiş bir rind gibi hayal ettiğimiz Nedim'in, genç yaşında “Müneccimbaşı Tarihi"ni Arapçadan Türkçeye naklederken öğrendiği derecede Roma ve Atina tarihini bilen gençler, bugün, bu aralık azdır. Nedim'in Arapça, Nefî́nin Farisî bildiği kadar, örneği Garp olan bugünkü nesil Fransızca biliyor ve Garp âlemini ihata edebiliyor mu?

Eski Türk şiirinin parlaklığıyla, yeni Türk şiirinin sönüklüğü yalnız bir ziya farkıdır. Hudâyî-nâbit dehaya özenenler ne Shakespeare'e aldansın, ne de Abdülhak Hâmid'e. 0 kadar sade-dil görünen Yunus Emre'nin hece vezninde yazdığına bakmamalı: Onun hece veznindeki felsefe ve istihzasını bugünkü şairlerimiz heceleyemezler bile.

(Akşam, nr. 735, 10 Teşrinievvel [Ekim] 1920, s. 3)

\section{İki Mübâriz Ruh}

Bu devletin ta kurulduğu günden bu kara günlerine kadar bariz iki ruhu vardır: Biri hürriyet diğeri medeniyet. Daha me'nus bir tabirle söyleyelim. Biri milliyet diğeri de siyasettir.

Kayı hanedanı sürülerini toplayan bir çoban gibi Anadolu'da beylikleri, tarikatları, aşiretleri hasılı birer türlü dağılmış duran Türkleri derleyip toparlayıp da bu devleti kurduğu zaman Türklükte milliyet ve siyaset aynı derecede mükemmel ve mütecanisti. Kayı beyleri ve silâh arkadaşları aynı derecede millî ve siyasî idiler. Bu devletin tesisini tetkik edenler o zaman bazen kılıcın pişdar, siyasetin dümdar bazen de siyasetin pişdar kılıcın dümdar olarak yürüdüğünü görerek hayret ediyorlar. 
Milliyet ve siyaset devletin tesisinden ta Sultan Selim-i Evvel'e kadar el ele yürüdü. O kadar ki eğer bu devletin bir tarih-i siyasîsi varsa o da ancak bu devre aittir diyebiliriz.

Süleyman-ı Kanunî'den sonra Türkler milliyetlerini saltanatın siyasetine feda ettiler, bir kenara çekildiler, hatta isimlerini unutturdular. Saltanat her zaman her yerde olduğu gibi bizde de bütün tebaasını aynı şefkatle kucaklamak iddiasında atebe olarak tecelli etti. Vakıa Türk devletinin muhasımları olan İslav, Cermen ve Latin devletleri bize yine "Türk, Türkler" demekte devam ediyordu. Frenkler bu hitaplarında haklı idiler çünkü bu meyvenin çekirdeği Türk'tü.

Daha Süleyman-ı Kanunî́nin cenazesi İstanbul'a girerken hudutsuz saltanatın bünyanı en mühim bir noktasından çatladı. Cenazenin yanında Kur'an okumakla muvazzaf Tarihnüvis Selânikî Mustafa naklediyor ki "Bahşiş açlığıyla gulüvv eden büyük ordu saray duvarları içine girdiği zaman 'vire more, vire more!' vaveylası yeri göğü sarsıyordu." Sultan Selim-i Sani “Varın sorun içlerinde bir Türkçe bilen var mı” dedi. Türk öyle bir devlet yapmış, o devlet öyle bir mahşer olmuştu ki Selim-i Sani bu mahşer içinde Türkçe bileni tellâlla aratıyordu. Türk yaptığı bal içinde boğulmuş arıya benziyordu.

O günlerden sonra saltanatı idare edenler gaza lafzı yerine"tedbir"den bahseder oldular. Tedbir o zamanlarda henüz kullanılmayan "siyaset" kelimesinin aynı idi. Gayet garip bir hadisedir ki Türklerde milliyet bağları gevşedikten sonra siyaset de körleşti. Sözde Fatih'ten evvelki vezirler ümmî, halbuki ondan sonraki vezirler, mollalar Enderun'dan, medreseden mezundular. Hakikatte Orhan ve Alaattin gibi devlet teşkilatından, Hudâvendigar ve Bayezıt gibi coğrafyadan, Fatih gibi elsineden, hendeseden, Selim-i Evvel gibi siyasetten anlayanları yoktu. Tedbir dedikleri ya müdara yahut da ekseriya olduğu gibi tedmirdi. Tedbir diye Yedikule'yi düşmana karşı badana eden yahut da Avrupa veraseti davalarının karşısında "Birbirlerine düşmüşler" diye alık alık söyleyen veyahut yüz otuz sene evvel Rusya'nın Avusturya ile müttefik olduğunun farkına varmayarak Rusya'ya harp açanlar hep o "Aristo-tedbir" vezirlerdir. Sokollu vezirden Reşit Paşa'ya kadar Osmanlı tarih-i siyasîsi hem gülünecek hem de ağlanacak bir hâldedir. Reşit Paşa'dan sonra Avrupa'yı şöyle böyle öğrendik. Reşit Paşa ilk defa olarak siyaseti saltanatın yegâne mihrakı gibi tesis etti. Seleflerine nispetle çok münevver olan bu vezir netice itibarıla tam selefler ayarındadır. Çünkü asrının yegâne doğru nazariyesi olan milliyeti zerre kadar idrak etmeyerek bu koca saltanatı metbu ve tebaa kaidesiyle ihya etmeye heveslendi. Hatta fazla olarak selefi o kurnaz fakat hiç zeki olmayan Hâlet Efendi'nin çığırında, taşranın asır-dide adem-i merkeziyet teşkilâtını bozdu. En yakın vilâyetler gibi en uzak eyaletleri merkeze doğrudan doğruya Babıali'nin kalem odalarına bağladı. Reşit Paşa ve tilmizlerinin mesut devrini hatırlayanlar bütün o sazlı sözlü Boğaziçi'ni, şen Rumeli ve bahtiyar Anadolu şehirlerindeki ucuzluğu, saadeti, rahatı hep bir kelimenin mucizesiyle ifade ederler: Siyaset.

Siyaset Reşit Paşa'nın keşfettiği "hacer-i felsefî" idi. Bütün o sulh u salah o saadet, o keyiflerin hâlıkı olan tılsım siyasetti. O devir adamlarının aklı sıra koca saltanat o hudutlarıyla 
bu tılsıma hürmeten duruyordu ve ilâ yevmi'l-kıyame durabilirdi de. Tanzimat'ın yalılarında yan gelip yatanlar yavaş yavaş milliyeti hor görmeye başladılar. Siyaset devrinde yeni bir Osmanlı numunesi türedi. Babıali'de çekirdekten yetişir, önü daima ilikli rütbe-i hamîseden bâlâ olana kadar temenna ede ede çıkar bir siyasî numunesi. Bir numune ki tamamıla fikirsizdir, dalkavuktur. Mülâhazaları civa gibi kayar, gayesiz olduğu için daima bedbin, echel olduğu için daima hodbin, hodbin olduğu için de milliyetten müteneffirdir. Bu neslin kafasında siyaset fikri milliyet fikrinden tamamıla ayrıldı.

Hakikatte siyaset mucizesi Reşit Paşa'nın eseri değildi. İngiltere ve Fransa Osmanlı saltanatı meselesinin hallini istemiyorlar, Babıali'yi koltuklarından tutuyorlardı. Yoksa bir taraftan milliyet nazariyesinin tebaamıza sirayeti, diğer taraftan da yeni devletlerin iktisadî ittisa'ı karşısında Osmanlı saltanatı o hudutların çerçevesi içinde kalamazdı, parçalanmak mukadderdi. Türklerin yegâne başvuracağı çare hakiki miktarları nispetinde kendi yurtlarında, o Avrupa milletlerinden hatta en küçüğünü numune alarak yeni ruhta ve yeni şekilde bir millet olmaktı. Eğer Hâlet Efendi çığırına devam edenler eski adem-i merkeziyeti kaldırmamış olsaydılar millet nazariyesine göre teşekkül edecek bir "Türk ili" bugün yine o nazariye ile teşekkül etmiş kardeş devletler ortasında vaziyetinden daha emin bulunurdu. Eski adem-i merkeziyeti kaldıranlar denilebilir ki bu devletin binasından evvel temelini bozdular.

Bugünkü zavallı hâlimize bakan Tanzimat bakiyesi siyasîler, milliyet nazariyesinin hariçte türediğinden ziyade, bizde de türediğini felâketimize menşe zannederler. İki seneden beri aramızda çıkan şikâk ve nifakın sebeplerini tetkik edince diyebiliriz ki bir taraf Reşit Paşa'nın "hacer-i felsefîsi" ile eski saltanatı idame edebileceğine kânidir. Diğer tarafta altı asır evvel Hudavendigâr toprağında doğduğumuz gibi tekrar doğmamızdan başka selâmet yolu olmadığına inanıyor. Cidallerimizin marazî şekillerini bertaraf ettikten sonra görülen hakikat budur.

(Akşam, nr. 801, 15 Kânunuevvel [Aralık] 1920, s. 1)

\section{Günün Fıkrası}

\section{Vatan ve Muallim Naci}

En bariz farîkası vatanperverlik olmayan Muallim Naci, muhacir olduğu için vatanı ne kadar fazla hissetmiş ve ne kadar fazla hissettirmiş. Varna'dan İstanbul'a hicret ettiği baharın bulutlarını da Türklerle beraber hicret ediyor sanacak kadar duyguludur.

O da olmuş vatan-cüda, seyyar

Ne hazin ağlıyor şu ebr-i bahar

Sonra İstanbul'da eski Osmanlı harsının son mütehassıslarıyla daldığı harabat âleminde vatan şöyle haraptır. 
Misafirim vatanın bir harâbe-zârında

der, bütün milletin inkıraz devrindeki hüsranını duyar. Mamafih vatanla yalnız mütehassis değil mütefekkirdir de:

Vatan hikâyesi hâb-âver oldu huzzâra

Ben ağladım yine tesir-i dâsitânımdan

derken büyük muasırı Namık Kemal gibi mürşit görünür. Ya Bağdat'a giderken duyduğu o şevkler, teessürler Varna medresesinde Arabî, İslâmî ve Mekkî Arapça öğrenmiş Türk'ün o duyguları:

Vatanımdan tebâüd etmiş idim

Sorma amma nasıl tebâüd ediş

Sonra Bağdat'a doğru gitmiş idim

Unutulmaz o âşıkâne gidiş

Fırat karşısında duydukları Türk teessürünün ne içli numuneleridir. Nehre bakıp da gözleri dolar.

Tunalaştın gözümde gittikçe

ağzından dökülür. Bütün o tabiat İslâmın matemleriyle giryandır.

Mağmum heva, Fırat çağlar

Sahilde bugün aşiret ağlar

Muallim Naci'nin Namık Kemal'e vatan şiirlerinde rüçhanı vardır demek bir Türk için küfür olur. Fakat Namık Kemal'in şiirlerinde tesadüf edilmeyen bir kelimeyi de ilk defa Muallim Naci söylemiş demek bir nimet-şinaslık olur:

Ben ki bir Türküm, unutmam Ca'ber'i

Türk olan nimet-şinas olmak gerek

Var yeri gitsem mezar-ı Türk'e dek

Muallim Naci'nin, vatana millete dair daha başka mısraları sayılabilir. Lakin bir beyti meşale gibi bir beyti vardır ki beyit değil bir nass, ledünnî bir hitap, zülcelâl bir hükümdür. O beyit de budur:

Ayrılan millet ittihadından

Kessin ümmidini muradından

(Akşam, nr. 810, 24 Kânunuvvel [Aralık] 1336, s. 3) 


\section{Vatan ve Abdülhak Hâmid}

Doğrudan doğruya aşka, ölüme, şevke münhasır birkaç eserinden başka Abdülhak Hâmid bütün eserlerinde: Eşber'de, Tezer'de, Nesteren'de, Ibnü'I-Musa'da, IIhan'da, Turhan'da, Zeynep'te, Duhter-i Hindu'da, Liberte'de, vatanı teganni etti. Genç Abdülhak Hâmid'in dehasını Namık Kemal, kendi ruhunun örsü üzerinde kendi üslubunun çekiciyle döverek bir kılıç yapmış. Bu kılıcın ilk işareti doksan dörtte [1878] Grandük Nikola İstanbul üzerine yürürken:

Düşman geliyor maksadı ifnâ-yı vatandır

Karşı duracak azmine ebnâ-yı vatandır

nakaratında görülür. Namık Kemal'in Hâmid'e pereştişkârca teveccühü, Hâmid'in Namık Kemal'e karşı daima artan perestişkârca hürmeti, yalnız bir üstad ve tilmiz rabıtası değil, bir mürşit ve bir mürit rabıtası hâlindedir. Hâmid üstadının bir zaman Türk edebiyatına çizdiği huduttan dışarı senelerce çıkmaz, fikrî istibdat devresi açılmışken Paris sefaretinde Midhat Paşa'nın şehadetini duyar Liberte'yi yazar. Abdülhak Hâmid son senelerde çıkan mektuplarının birinde topu iki güzel eseri kalacağını söylüyor. Bunlar da "Merkad-ı Fatih’i Ziyaret" ve "Kabr-i Selim-i Evvel'i Ziyaret" unvanlı iki uzunca manzumedir. Abdülhak Hâmid'in hayranlarını şaşırtan bu sözü birinci değilse bile ikinci manzume için tamamıla variddir. "Kabr-i Selim-i Evveli Ziyaret" Abdülhak Hâmid'in bilâ-şekk ü şüphe en güzel [manzumesidir]. Şimdiye kadar hiçbir Türk hiç[bir] İslâm şairi fikrin vatan mevzuunda yüksek bir devresine yükselemedi."Merkad-ı Fatihi Ziyaret" bu manzumenin bir eşi [olarak] gerek ilhamındaki şiddet gerek de [üslubundaki] hararet itibariyle eşine dûndur. Abdülhak Hâmid Paris sefaretindeyken İstanbul'a bir seyahatte bulunur. Bir gün Pîrîzâde Osman Beyle beraber Sultan Selim-i Evvel'i ziyarete gider, manzumenin ilhamını o gün türbeden alır. O heybetli şekli verdikten sonra onun büyükbabası, şehrin sahibi Fatih'e [aynı] surette bir manzume vücuda getirmeyi bir günah korkusu gibi duyar. Fatih'i de cism ü ruhunun bütün kuvvetini vererek ikinciye de vücut verirse de birincinin derecesine varamaz. Acaba bu sır Hâmid'in dimağına arız olan taabbüde mi yoksa Selim-i Evvel'in İslâm emelini fazla bir heybetle temsil ettiği, beslediği perestişte midir?

"Selim-i Evvel'i Ziyaret" de yalnız yirmi benttir ki birbirinden yüksek Himalaya dağlarının silsilesi heybetindedir. Selim fikriyle, emeliyle, Müslümanlığıyla, ordularıyla, seferleriyle, önünde açtığı ufukla, arkasında bıraktığı eserle görülür.

Önünde na-mütenahiliği kılar tenvir.

Peyinde sâyesi kalmış bu devlet ü millet!

Abdülhak Hâmid türbede kendi kendine sorar:

Acep ne hâle girerdi duran huzurunda

Gelir zevâline baktıkça dillere dehşet! 
Selim'in hayattan ebediyete göçüsü manevî bir hadisedir:

Memât çekmede pîşinde meş'al-i tekbir Hayat kılmada ardında nâle-i hasret. Salâ iner ser-i bâlînine cevami'den Urur minare-i bâlâ derinde beş nevbet Bu şehriyar değil miydi Hâdimü'l-Haremeyn Mutâ'-ı cümle-i akvâm iken o zî-kudret Edeb, sükûnet-i kübrasına durur divan Zekâ, tutar ciheteyninde şem'a-i türbet Kitab-ı Hazret-i Yezdan ser-i mezarında Olur bu hâl ile Perverdigâra hem-sohbet Hemişe velvele-i kibriyaya ma'kes olur Sükût içinde bu hîçî-serây-ı pür-vahdet

Selim hayatında acaba nasıl bir Türk padişahı, nasıl bir halifeymiş:

Deminde râkib-i rahş-ı gaza, ne afet imiş

Aceb bu saika-yı ser-be-bister-i hayat

Kopardı reh-güzerinde kıyamet-i a'dâ

Akardı pâyine mahşer-misal bir millet

Son mısralarda artık Selim bütün çehresiyle görünür:

Elinde meş'ale-i maneviyye-i tevhid Ederdi Şark ile Garb'ı ziyasına davet İkinci himmete mutlak düşerdi Hind ile Çin Yetişti Mısr ile İran'ı fethe bir himmet Zalâm içinde hakikat tenevvür etmişti Yazık ki barîka-yı ömrü söndü bî-müddet Bu kubbe Türbe-i Sultan Selim-i Evvel'dir Bu türbe kıble-i Osmâniyân'dır ey ümmet

Abdülhak Hâmid'in diğer eserlerinden daha başka berceste mısralar toplanabilir. Lâkin belki hepsinden güzeli bundan yirmi üç sene evvel Kırım'da şehit olmuş askerlerimizi ziyaret ettiği sırada söylediği parçalardır. Abdülhak Hâmid Kırım’a bir İtalyan bir de Rus zâirle beraber gider. Görür ki o zamanki müttefik ve muhâsımlarımızın ölmüş askerlerine taş sandukalar, güzel kitabeler ithaf edilmiş. Bizim şehitlerimiz ber-mutad sandukasız nâm u nişansız. Hâmid, Rumeli ve Anadolu'nun o mezarlıkta dolaşan ruhlarına, âdeta çocuklarla konuşur gibi teselli verir:

Bunda herkes bugün seferberdir

Menzil ancak gubâr-ı esmerdir

Olmasın rûh-i pâkiniz muğber! 
Sonra Hâmid Kırım'ı arkadaşlarıyla beraber terk ettikten sonra vapurdan şehitlerimizin yattığı yere son bir defa daha bakar ve orada yattıklarına dair semada bir işaret görür. Bu mısraları ne kadar samimi vatan hislerini câmi:

Şimdi biz doğrulup denizde yola

Bakarız dûrdan Sivastopol'a

Görünür fevkimizde bir peyker

Elveda elveda elveda ey askerler

[Not]: Âli-kadr bir muhterem karimizden şu mektubu aldım:"Günün Fıkrası'nda Muallim Naci'nin vatana, millete dair yazdığı beyite bir nass, ledünnî bir hitap, zülcelâl bir hükümdür diyorsunuz. Cidden böyledir, karilerinizce malûm olmayan bu beyiti öğrettiğinizden dolayı size şükran bir emr-i tabiîdir. Selim-i Evvel hazretlerinin bu beyitine ne dersiniz?"

Milletimde ihtilâf ü tefrika endişesi

Kûşe-i kabrimde hatta bî-karar eyler beni

Itttihadken savlet-i a'dâyı def'e çaremiz

İttihad etmezse millet dağdar eyler beni

(Akşam, nr. 812, 26 Kânunuevvel [Aralık] 1920, s. 2) 
